Article

\title{
The Jungle of Support: What Do We Really Mean When We Say "Residents' Support"?
}

\author{
María Ángeles Plaza-Mejía ${ }^{1, *}$, Nuria Porras-Bueno ${ }^{1, *}$ and David Flores-Ruiz ${ }^{2}$ (E) \\ 1 Department of Business Management and Marketing, University of Huelva, 21017 Huelva, Spain \\ 2 Department of Economy, University of Huelva, 21017 Huelva, Spain; david.flores@dege.uhu.es \\ * Correspondence: plaza@uhu.es (M.Á.P.-M.); porras@uhu.es (N.P.-B.)
}

Received: 21 August 2020; Accepted: 16 September 2020; Published: 21 September 2020

check for updates

\begin{abstract}
The aim of this research is to provide a conceptual framework to facilitate the standardization of the concept of "residents' support" in tourism studies. The model is designed to prevent ambiguity and confusion that may arise in the use of the generic term "residents' support." Social Exchange Theory and the Theory of Reasoned Action will be incorporated for the purposes of contextualizing the term "residents' support" with respect to three dimensions: attitudinal, intentional, or behavioral. A longitudinal analysis of the term "residents' support" will be conducted on the basis of the proposed model. Fifty-four articles published between 2004 and the first quarter of 2020 have been studied to classify the items used to create the construct of "residents' support" in tourism studies and to draw conclusions about the work of scholars and tourism agents.
\end{abstract}

Keywords: residents' support; social exchange theory; theory of reasoned action; attitude; intention; behavior

\section{Introduction}

Five decades have passed since 1970, when interest was first shown in analyzing how residents of a destination perceive the impacts of tourism and how this perception is linked to the support they provide for further development. [1] Suess, Woosnam, and Eru, (2020) claim that these studies have been vital in explaining the sustainability of tourism in destinations and recommending policies related to visitor management and industry development.

An interesting perspective on the state of the matter can be found in the review of summary articles published by [2] Harrill (2004), [3] Deery, Jago, and Fredline (2012), [4] Chen and Raab (2012); [5] Nunkoo, Smith, and Ramkissoon (2013), [6] Sharpley (2014), [7] Boley and Strzelecka (2016), and [8] Gursoy, Ouyang, Nunkoo, and Wei (2018). The importance of this set of articles is that they offer a theoretical analysis and a review of the existing literature regarding the perceptions and/or attitudes of residents towards tourism.

Throughout the years in which research has been conducted, efforts have been made to create a more standardized theoretical framework of reference. The research in this area appears to be transitioning away from a poor level of methodological refinement and an inadequate theoretical framework towards a more advanced level, thereby striking a better balance between methodology and theory ([5] Nunkoo, Smith, and Ramkissoon, 2013; [6] Sharpley, 2014).

As the volume and complexity of publications has increased, the confusion surrounding the terminology has also grown apace. This is becoming more acute at a time when the sector recognizes the need to look beyond residents' attitudes and study their behavior towards tourism. While the co-existence of terms such as support, perceptions, attitude, intention, and behavior in current research both enriches and expands the object of the study, it also adds to the confusion and ambiguity surrounding the terminology used. In this sense, [9] Prayag (2013) stresses the need to distinguish 
between attitudes and support, and [10] Carmichael (2000) claims that perceptions and attitudes are not synonymous with behavioral intent, which highlights the need for terminological standardization.

Indeed, as stated by [11] Jackson and Inbakaran (2006), the main challenge for resident studies is to focus on the real question of "Do residents act on their attitudes toward tourism and its future development?"

The existence of an "attitude-behavior gap" ([12] Oates and McDonald, 2014; [13] Juvan and Dolnicar, 2014) or a "value-action gap" ([3] Deery, Jago, and Fredline, 2012) implies that enquiring about attitudes and the intention to act in a certain way does not reveal much about actual behavior and that which the residents claim they are willing to do is not what they actually do.

Many authors have expressed interest in filling the "gap" ([14] Boley, Strzelecka, and Watson, 2014; [15] Gursoy, Chi, and Dyer, 2009; [16] Gursoy and Rutherford, 2004; [17] Hasani, Moghavvemi, and Hamza, 2016; [18] Nunkoo and Gursoy, 2012; [19] Nunkoo and Ramkissoon, 2011a; [20] Nunkoo and Ramkissoon, 2011b; [21] Nunkoo and Smith; [5] Nunkoo, Smith, and Ramkissoon, 2013; [6] Sharpley, 2014).

Closing the "attitude-behavior gap" in resident studies implies working with the concepts of attitude, intention, and behavior sometimes used in the context of the generic term of support. It is the term "support" that requires further attention because—as stressed by [7] Boley and Strzelecka (2016) there is a lack of consensus about the concept and this makes it difficult to compare the different studies. In fact, it could be said that "residents' support" is a catch-all term that sometimes refers to residents' attitudes, and sometimes to residents' intentions or behaviors. What do we really mean when we say "residents' support"? Is the use of term only relevant when researching "residents' support" in tourism development? What problem does the use of standardized terminology resolve? These are the research questions that this work is centered around. The use of standardized concepts is an important issue in the scientific community: "certain things should not be taken for granted, among them ... the precise meaning of words that are at the heart of your discipline" [22] (Angier, 2009).

As described by [23] Bergner (2011), concepts are not theories, and in science they are indispensable, pre-empirical elements in distinguishing any empirical phenomenon. An appropriate set of concepts facilitates the formulation of theories, the establishment of hypotheses, and comparison between studies.

It is not only scholars but also tourism agents that can benefit from efforts to standardize terminology, because, from a practical point of view for a sustainable tourism development, it could not be the same to achieve the "residents' support" from an attitudinal, intentional, or behavioral point of view.

To answer the research questions, Social Exchange Theory (SET) and the Theory of Reasoned Action (TRA) will be incorporated in order to propose a conceptual model for residents' support. While SET has been the theory generally used in residents' research to explain the relationship between perceptions of and attitudes towards tourism [24] (Ward and Berno, 2011), TRA goes further by combining the concept of attitude with that of intention and behavior.

Taking the approach proposed in the conceptual model, a longitudinal analysis of the term "residents' support" will be conducted using publications from three leading tourism journals (dated between 2004 and the first quarter of 2020). The analysis of the different items used to develop the construct will allow us to clarify the meaning of the support construct from a terminological standpoint, determining whether it has been used as a substitute term for attitude, intention, and/or behavior.

Based on the conclusions drawn, it will be possible to provide some recommendations to scholars and tourism agents for the use of the term "residents' support." 


\section{2. "Residents' Support" in the Context of SET and TRA: Proposed Conceptual Model}

\subsection{Residents' Perceptions and Attitudes-The SET Perspective}

Despite being criticized for lacking theoretical sophistication, there is no doubt that SET has been the theory most commonly used to date to predict and explain residents' attitudes toward tourism development [24] (Ward and Berno, 2011).

Social Exchange Theory states that residents assess tourism in terms of social exchange by making approximate mental calculations of the benefits and costs obtained in the present, or in the future, in exchange for the services that they and their community provide to tourists. The impacts of tourism are considered positive when the exchange of resources is high and, conversely, they are considered negative when the exchange of resources is low [25] (Ap, 1992).

Serious efforts have been made to identify and classify the factors influencing residents' attitudes. These include demographic factors, personal factors, social factors, and factors related to tourism [11] (Jackson and Inbakaran, 2006); socioeconomic factors, spatial factors, and factors of economic dependence [2] (Harril, 2004).

Most importantly, residents' perception of the positive and negative impacts of tourism is the principal variable that determines their attitude towards tourism ([26] Kayat, 2002; [27] Ko and Stewart, 2002). [28] Vargas-Sánchez et al. (2011) argue that the most powerful predictor of residents' attitudes is the perception that the positive impacts outweigh the negative ones. More specifically, the perception of the positive impacts ([29] Perdue et al., 1990; [30] Gursoy et al., 2002; [16] Gursoy and Rutherford, 2004; [31] Gursoy and Kendall, 2006; [32] Vargas-Sánchez et al., 2009), with particular regard to economics ([33] Dyer et al., 2007; [32] Vargas-Sánchez et al., 2009), is the variable that appears to have the greatest influence. With its meta-analytic approach, the article by [8] Gursoy et al. (2018) offers a good synthesis of the relationship between both variables.

The difficulties arising in the comparison of the results from various studies due to the different definitions and scales of measurement used for the two variables (perceptions and attitudes) are already widely known.

On the one hand, the variable of residents' perception has been configured with different degrees of aggregation. Some studies list a range of positive and negative impacts perceived as economic, socio-cultural, and environmental aspects [34] (San Martin et al., 2017); sometimes they are grouped as positive and negative impacts; and occasionally, a variable of subjective global perception "in general, the benefits derived from tourism outweigh the costs" is used [35] (Vargas-Sánchez, Porras-Bueno, and Plaza-Mejía, 2014).

On the other hand, the variable of residents' attitudes is not exempt from the confusion caused by a lack of standardization. This is not only due to the measurement scale ([30] Gursoy, Jurowski, and Uysal, 2002; [16] Gursoy and Rutherford, 2004; [32] Vargas-Sánchez, Plaza-Mejía, and Porras-Bueno, 2009; [28] Vargas-Sánchez, Porras-Bueno, and Plaza-Mejía, 2011) but also the scope of the concept that ranges from "attitude towards tourism in general" ([9] Prayag, 2013; [32] Vargas-Sánchez et al., 2009) to "attitude towards tourists," or even "attitude towards a specific model/segment of tourist development" ([33] Dyer, Gursoy, Sharma, and Carter, 2007; [31] Gursoy and Kendall, 2006; [15] Gursoy, Chi, and Dyer, 2010; [27] Ko and Stewart, 2002).

In spite of these issues, all the models defined by scholars in this field are underpinned by the fact that how residents perceive the impacts of tourism determines their attitude towards it.

\subsection{From Residents' Aattitude towards Residents' Intentions and Behaviors-The TRA Perspective}

Interest in resident studies is starting to move beyond attitude and delve into its relationship with residents' intentions and/or behaviors towards tourism. According to [34] San Martin, García, and Herrero (2017), pro-tourism behavior is similarly influenced by the attitude towards tourism development and the attitude towards tourists. [36] Ribeiro, Pinto, Silva, and Woosnam (2017) claim that there is a direct positive link between positive attitudes and pro-tourism behavior, and a direct 
negative link between negative attitudes and pro-tourism behavior. [37] $\mathrm{Wu}$, Tsai, and Lee (2017) indicate that attitude is the most powerful variable that can influence intentions regarding tourism. However, some studies have shown that attitudes are weakly associated with behavior [38] (Krosnick and Richard, 1995), that behavior is influenced by more variables than attitudes [39] (Azjen and Fishbein, 1980), and that the most intense attitudes are those that best predict actual behavior [40] (Howe and Krosnick, 2017).

When research focuses on residents' intentions regarding tourism development, various expressions are used to refer to the construct, such as intentional behavior [41] (Fishbein and Ajzen, 1975), intention to act (11) (Jackson and Inbakaran, 2006), or intention to support [42] (Kwon and Vogt, 2010), and are shaped by a variety of items that express a certain intention, e.g., "I am willing," "I would like," "I would be willing to," and "I intend to."

When researching behavior, the issues created by the variety of terms and items surrounding the construct ([43] Lepp, 2007; [44] Peter, Chung-Shing, and Legerer, 2018; [9] Prayag, Hosany, Nunkoo, and Alders, 2013; [34] San Martin, García, and Herrero, 2017) are compounded by those caused by the variety of behaviors that residents can display towards tourism development: participation in tourism activities in their communities [34] (San Martin et al., 2017); assistance at organized tourism events ([45] Chen and Segota, 2015; [34] San Martin et al., 2017); destination branding ([46] Chen and Dyer, 2018; [47] Juring, 2017; [48] Walls, 2008); positive WOM to tourists, gratuitous referrals ([46] Chen and Dyer, 2018; [45] Chen et al., 2015; [47] Jeuring and Haartsen, 2017; [48] Walls, Shani, and Rompf, 2008); providing information to potential tourists [49] (Arsal, Woosnam, Baldwin, and Backman, 2010); entrepreneurial behavior towards tourism [50] (Su and Wall, 2014); ambassador behavior ([46] Chen, Dwyer, and Firth, 2018; [47] Chen et al., 2015); traveler/visitor behavior ([46] Chen et al., 2018).

The TRA developed by [41] Fishbein and Ajzen (1975), expanded by the Theory of Planned Behavior (TPB) developed by [51] Ajzen and Madden in 1986, can be regarded as an effective initial solution that incorporates attitude, intention, and behavior, and bridges the "attitude-behavior gap." It also prevents confusion of these three terms. Not surprisingly, this theory attempts to predict behavior on the basis of attitude. As shown in Figure 1, according to this model, behavior is directly determined by intention. This variable is, in turn, influenced by another two: attitude (the subject's positive or negative assessment of behaving in a certain way) and subjective norms (the subject's judgement of how likely it is that people important to him/her would expect him/her to behave as predicted). In turn, attitude is determined by subjective probability and subjective desirability. Subjective norms depend on normative belief and the motivation to conform to these beliefs.

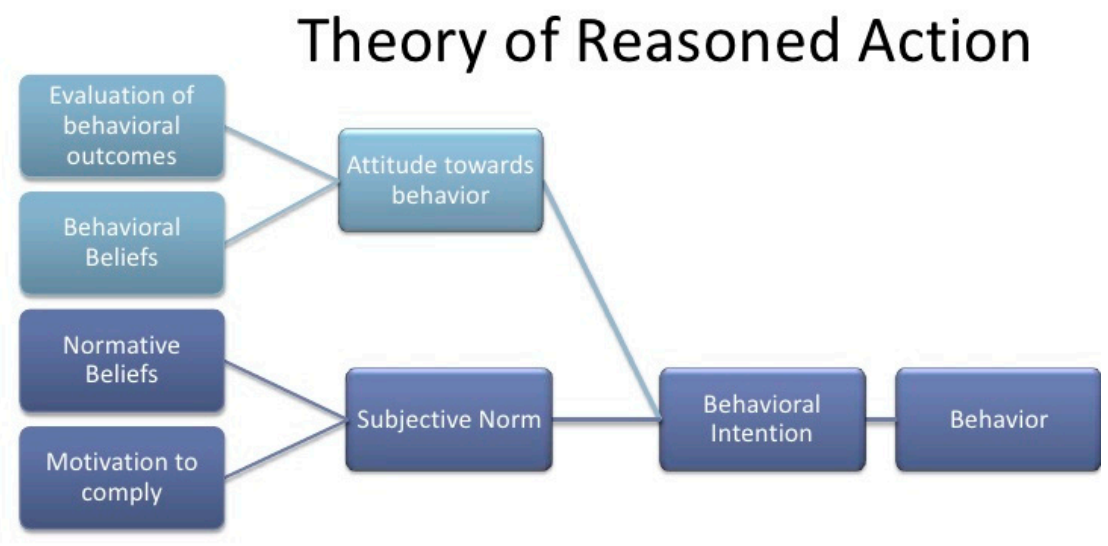

Figure 1. Theory of Reasoned Action; Source: [41] Fishbein and Ajzen (1975).

\subsection{A Conceptual Model for "Residents' Support"}

In the light of the above, our goal is to propose a conceptual framework that integrates SET and TRA in order to facilitate a more standardized approach to the concept of "residents' support", establishing whether it has been considered from an attitudinal, intentional, and/or behavioral perspective. 
It should be noted that our proposed conceptual model (Figure 2) only partially considers the TRA, exclusively incorporating the terms relating to attitude, intention, and behavior (attitude towards behavior, intentional behavior, and actual behavior), and thus excluding the concept of subjective norm. The reason for this is that these are the concepts to which the term of support could refer.

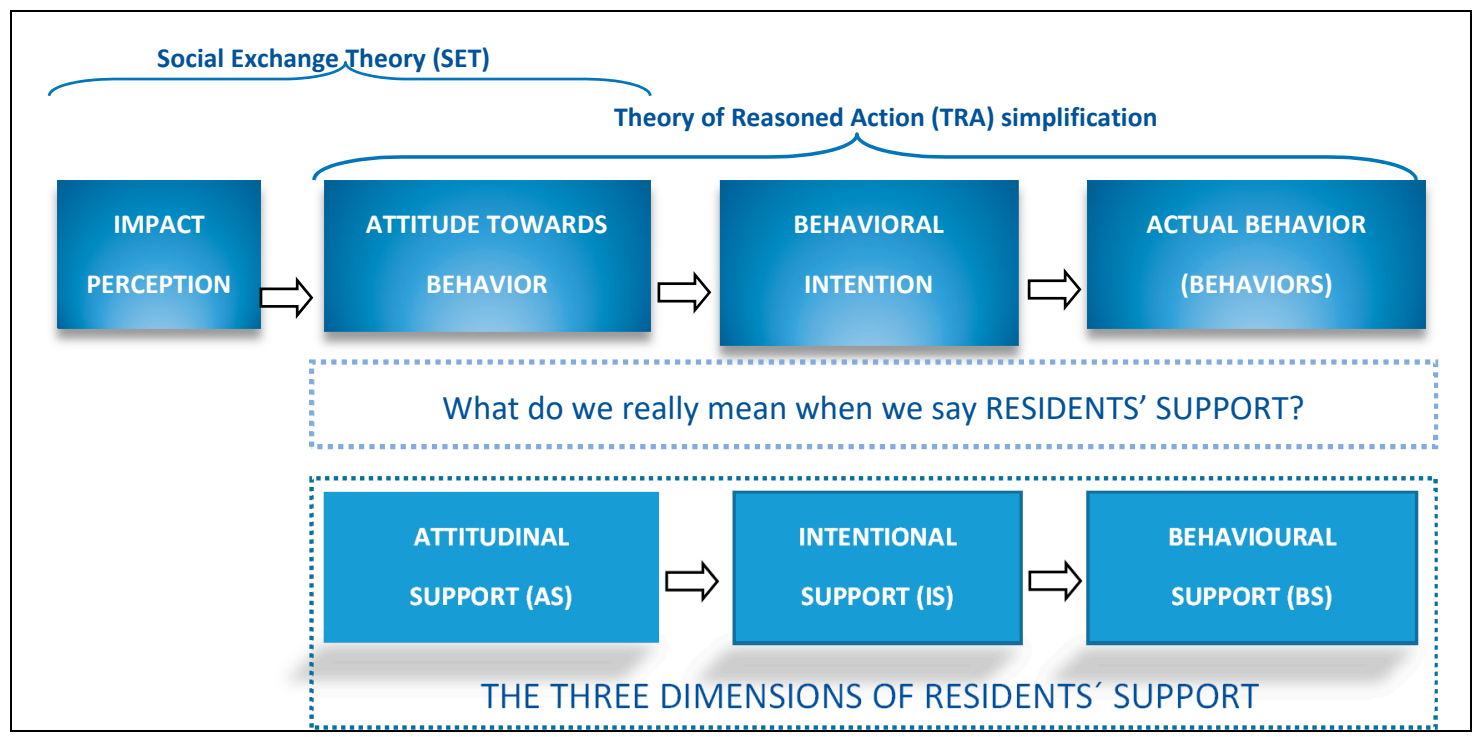

Figure 2. A proposed model for the conceptualization of the "residents' support" concept. Source: elaborated by authors.

Firstly, it should be emphasized that-from a psychological perspective-attitudes, intentions, and behaviors are different concepts with a specific definition, while the term "support" remains broad and generic.

The term "support" is defined by the Cambridge Dictionary as: "to agree with and give encouragement to someone or something because you want him, her, or it to succeed. Approval and encouragement given to someone or something; to help someone emotionally or in a practical way; to accept something and allow it to happen".

Attitude is defined as the degree to which a person has a favorable or unfavorable evaluation or appraisal of the behavior in question ([52] Ajzen, 1991, p. 188); general assessments (positive or negative) that people make about what happens around them, including people, ideas, and objects ([53] Eagly and Chaiken, 1993; [54] Petty and Cacioppo, 1986). Attitudes can hold affective (emotions), cognitive (beliefs), and behavioral information, but they are a single global mental construct relating to the summary of all information reported in an assessment. Attitude is usually measured with items that include the following expressions: I support . . ; I believe . . ; I am happy ... ; I am against ... ; I am proud . . ; I think that ... ; I oppose ... .; I perceive ...

Intention is "the amount of effort one is willing to exert to attain a goal" [52] (Ajzen, 1991). From the review of various articles it is possible to identify the expressions most frequently used ([55] Kim, M. and Cichy, R. (2017); [56] Kim, Y.H., Kim, M., and Goh, B. (2011); [57] Han, H., Hsu, L., and Sheu, C. (2010), [58] Amaro. S., and Duarte, P. (2015)): If I ... I will . . ; I am willing to ... ; I will ... ; I plan to ... . I I intend to ...; My intentions are ...; I expect I will ... . when ...; I expect to ... . in the near future; I am determined to ... ; The probability that I will ... ; The likelihood that I would..; If I had to ... ; I would have ...; The thought of ... Intentions are "self-instructions to perform particular actions directed towards attaining outcomes. Intentions capture both the level of the set goal or behavior and the person's level of commitment" [59] (Sheeran and Webb, 2016).

Finally, behavior is "an organism's external reactions to its environment. Human behavior is the term used to describe a person's actions and conduct. Is an attempt on the part of an individual to 
bring about some state of affairs" [60] (Ossorio, 2006, p. 49). It is common to use expressions such as: I practice ... ; I help ... ; I recommend ... ; I visited ...

Figure 3 shows an example of how each of the previous concepts could be reflected, for the case of a specific typology of resident behavior (the information that residents give to the tourist about things to see or do in the locality).

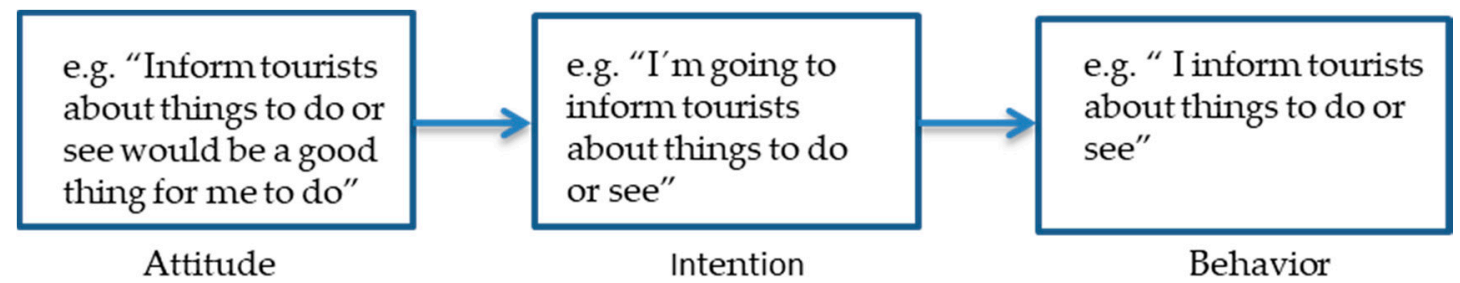

Figure 3. Example to illustrate the difference between the concepts resident' attitude, intention, and behavior. Source: elaborated by authors.

The proposed model outlines a threefold approach to "residents' support" as a dependent variable: attitudinal support (AS), intentional support (IS), and behavioral support (BS). This implies that the resident's support could mean different things depending on whether it is considered from an attitudinal, intentional, or behavioral perspective.

The model is designed to prevent ambiguity and confusion that may arise in the use of the generic term "residents' support" in resident studies. The aim of the conceptual model is not to standardize the concepts of residents' attitudes, residents' intentions, or residents' behaviors. The proposed model is also not designed to recommend the generic term "residents' support" to be selected earlier than before.

As the term "residents' support" is not exclusively linked to attitude, intention, or behavior, the model aims to highlight the importance of establishing the meaning (attitudinal, intentional, or behavioral) of the term "residents' support" prevalent in each investigation, delimiting a priori what dimension/s of support is/are to be analyzed in each study, and thus to avoid the confusion created when it is used as a catch-all term.

The proposed conceptual model offers two benefits: firstly, its use facilitates comparison between different research studies (inter-research level) by clearly identifying the meaning of the term "residents' support" that each of them refers to. Secondly, it is advantageous at the intra-research level (in an individual research) because it prevents the creation of a confusing and ambiguous "residents' support" construct due to the inclusion of a mixture of items pertaining to very different dimensions of support.

Finally, it also illustrates the importance of reducing the "attitude-behavior gap" by considering attitudes, intentions, and behavior, which favors the development of studies that include two or more constructs to measure "residents' support" from two or more different dimensions.

\section{Methodology}

Having clarified the terms of the proposed conceptual model, we will conduct a longitudinal analysis of the term "residents' support" in residents' studies in the field of tourism, taking the approach established in Figure 2 as a basis.

We will examine studies published in three leading tourism journals (Annals of Tourism Research, Journal of Travel Research, and Tourism Management) between 2004 and the first quarter of 2020. There are several reasons for this selection. First of all, the mere fact that they are academic journals guarantees that they are a source of information that contributes to research in a field ([61] Xiao \& Smith, 2005; [8] Gursoy et al., 2018). Secondly, they are the three leading academic journals in the field of tourism [62] (Journal Citation Reports, 2018), and lastly, the three journals have different editorial aims, which ensures that different theoretical and applied approaches are covered in the examination of the object of study [5] (Nunkoo et al., 2013). 
Limiting the review to these journals allows for initial testing of the proposed model, although we are aware that further relevant studies published in other scientific journals have been excluded from the analysis ([63] Simpson and Bretherton, 2009; [19] Nunkoo and Ramkissoon, 2010; [64] Ayazlar and Ayazlar, 2016; [17] Hasani, Moghhavvemi, and Hamzah, 2016; [65] Rasoolimanesh, Jaafar, and Barghi, 2017; [37] Wu, Tsai, and Lee, 2017; [34] San Martin, García de los Salmones, and Herrero, 2017; [66] López, Virto, Manzano, and Miranda, 2018; [67] Su, Huang, and Huang, 2018; [68] Schnitzer, Walde, Scheiber, Nagiller, and Tappeiner, 2019; [69] Chen, Wang, Li, and Lawton, 2019).

A three-step process was used to select the studies. Firstly, the authors conducted an online search in the databases of the journals combining the concepts of support and residents/host/locals/community in the title, key words, and/or abstract. Secondly, only full-length and empirical articles were selected to ensure that relevant information could be identified in the methods section, particularly the name given to the dependent variable measuring the residents' support of tourism, as well as the items used in its composition. That is why some qualitative works were eliminated despite their focus (e.g., [70] Monterrubio, Andriotis, and Rodríguez-Muñoz, 2020; [71] Spencer and Nsiah, 2013). Thirdly, studies in which "residents' support" was measured using a variable that does not expressly include the term "support" in its wording were eventually excluded ([72] Maruyama and Woosnam, 2015; [36] Ribeiro Pinto, Albino, and Woosnam, 2017; [73] Strzelecka, Boley, and Woosnam, 2017). This three-step selection process made it easier to focus on the purpose of the research, which, as mentioned above, is to identify what we really mean from a terminological standpoint when we say "residents' support."

Finally, a total of fifty-three articles met the inclusion criteria. Each article was then reviewed in order to identify seven major categories: authors, publication year, region under study, theoretical approach, method of data analysis, the precise term given to the support construct, and, when expressly identified, the items that formed the "residents' support" construct. The first six categories have been summarized in Table A1.

Following that, for each individual study we searched for the specific items constituting the "residents' support" construct and, depending on the proposed conceptual model, classified them according to the support dimension they were related to: attitudinal support (Table A2), intentional support (Table A3), and/or behavioral support (Table A4).

\section{Results}

Table A1 (see Appendix A) collates information pertaining to authors, publication year, region under study, theoretical approach, method of data analysis, and the precise term given to the support construct. A column has been added that identifies, for each article, the dimension or dimensions of the support that it outlines, based on the individualized analysis of each of the items used in the construct (as shown in Tables A2-A4) (see Appendix B). The first columns of the table provide some general and methodological information about the selected works. The columns "Name of the support construct" and "Items related to ... " serve to clarify whether the construct "residents' support" is standardized across different studies; in other words, whether the construct used in the collection of articles was unequivocally linked to a single specific dimension of support, or, on the contrary, whether the dimension of support used in the studies varied.

The studies conducted vary greatly in terms of the geographical location of the resident populations examined, with a total of 20 different countries. The leading countries analyzed were the USA (26\%), China (11\%), England (6\%), Korea, Mauritius, Malaysia, and Brazil (each accounting for 5\%), Australia, Canada, Greece and Iran (each accounting for $4 \%$ ). Other regions with a token presence include Spain, Pakistan, Poland, Taiwan, Qatar, the Caribbean, Jamaica, and South Africa. They are grouped into the following major world regions: America (40\%), Asia (25\%), Europe (14\%), Middle East $(10 \%)$, Africa (8\%), and Oceania (3\%). A longitudinal analysis reveals the clear prevalence of U.S. studies in the early years, accounting for $64 \%$ of those analyzed between 2004 and 2010 . There has been a progressive diversification of the areas under study since then, to the extent that most of the work 
carried out in relation to Chinese residents falls within the three-year period of 2015 to 2017, and all the studies from the Middle East are concentrated in the final period of study (2017 to 2020).

With respect to the authors, it is important to note the presence of ten articles in which Dogan Gursoy is the co-author $(18.5 \%)$, six are signed by Kyle Maurice Woosnam—one of them exclusively- $(11.1 \%)$, and there are another six in which Robin Nunkoo is the co-author (11.1\%).

As would be expected given the tradition in resident studies, the theory on which most of the analyzed articles are based is SET (79.2\%); in some cases exclusively $(54,7 \%)$ and in others it is accompanied by other complementary theories, and those with similar weighting ( 3 out of 43 cases) include TRA, Place Identity Theory (PIT), and Weber's Theory of Formal and Substantive Rationality (WFSR). SET is accompanied by the Stakeholder Theory on two occasions. Additional theoretical approaches used alongside SET to support the works included the following: Authenticity Perception, Emotional Solidarity, Community Attachment, Subjective Well-Being, Bottom-up Spillover Theory, Social Carrying Capacity Theory, Fairness Heuristic Theory, Social Dilemma Theory, and Cognitive Appraisal Theory, Destination Life Cycle.

The studies that did not apply SET (11 out of 53, i.e., 20.7\%) used a range of approaches such as the Theory of Community Attachment, Stakeholder Theory, Institutional Theory, Quality of Life, Self-Perception Theory, Theory of Formal and Substantive Rationality, Complexity Theory, Weber's Theory of Substantive and Formal Rationality, Attitude Theory, Resident Empowerment, and Tourism Use History.

In terms of the statistical methodology applied, it should be noted that 38 out of 53 (71.7\%) studies use the structural equation model (SEM), mainly through covariance-based SEM (CB-SEM) (33 out of $38,86.8 \%)$, and 5 out of the $38(13.2 \%)$ studies conducted use partial least squares SEM (PLS-SEM). Modeling is usually accompanied by exploratory and/or confirmatory factor analysis and principal component analysis. The remaining $28.3 \%$, which do not use SEM, used other statistical methods including Multiple Regression Analysis (17\%) and, less frequently, techniques such as exploratory and/or confirmatory factor analysis, principal component analysis, ANCOVA, and ANOVA.

Having summarized the most general and methodological aspects of the studies reviewed, the authors then conducted a full review of the items used to shape the concept of support in 53 of the studies compiled. Each study was assigned to the most appropriate support dimension column(s) (attitudinal, intentional, or behavioral) (see Table 1) in accordance with the scheme of Figure 1. It is important to point out that some articles are listed in several support dimension columns; this is because the items used to shape the support construct are related to several of the dimensions defined and not to a unique dimension as would be desirable.

Table 1. Items most commonly used in each of the support dimensions.

\begin{tabular}{|c|c|}
\hline Support Dimensions & Items \\
\hline Attitudinal & $\begin{array}{l}\text { I support ... } \\
\text { Opinions regarding what represents or can represent tourism } \\
\text { Opinions regarding the role that public authorities play in } \\
\text { tourism } \\
\text { I believe ... } \\
\text { I am proud ... }\end{array}$ \\
\hline Intentional & $\begin{array}{c}\text { I would support ... } \\
\text { I will ... } \\
\text { I need to .... } \\
\text { I want to ... }\end{array}$ \\
\hline Behavioral & $\begin{array}{l}\text { I participate ... } \\
\text { I cooperate ... } \\
\text { I visited ... } \\
\text { I want to continue.... } \\
\text { I was a volunteer... }\end{array}$ \\
\hline
\end{tabular}


With respect to the term used for the support construct, "support for tourism development" has been used most frequently with 17 constructs out of the 57 analyzed (29.8\%) (some articles produce 2 support constructs), followed by "support for tourism" with $13(22.8 \%)$, "support for mega-events" with $10(17.5 \%)$, and the support for certain types of tourism, such as Airbnb, short-term vacation rentals, World Heritage Sites, Red tourism in China, peer-to-peer accommodation, alternative tourism, and mass tourism. Consequently, from the outset it has been possible to see how the concept of support is used to address residents' support in a wide variety of situations associated with tourism in their localities, including tourism development in general, support for certain events, types of tourism, and tourism policy.

Furthermore, the last three columns of Table A1 (see Appendix A) indicate the type of support given by the resident for these developments. These types of supports are divided into the three dimensions of the support concept: attitudinal, intentional, and behavioral. Figure 4 offers a summary of the findings.

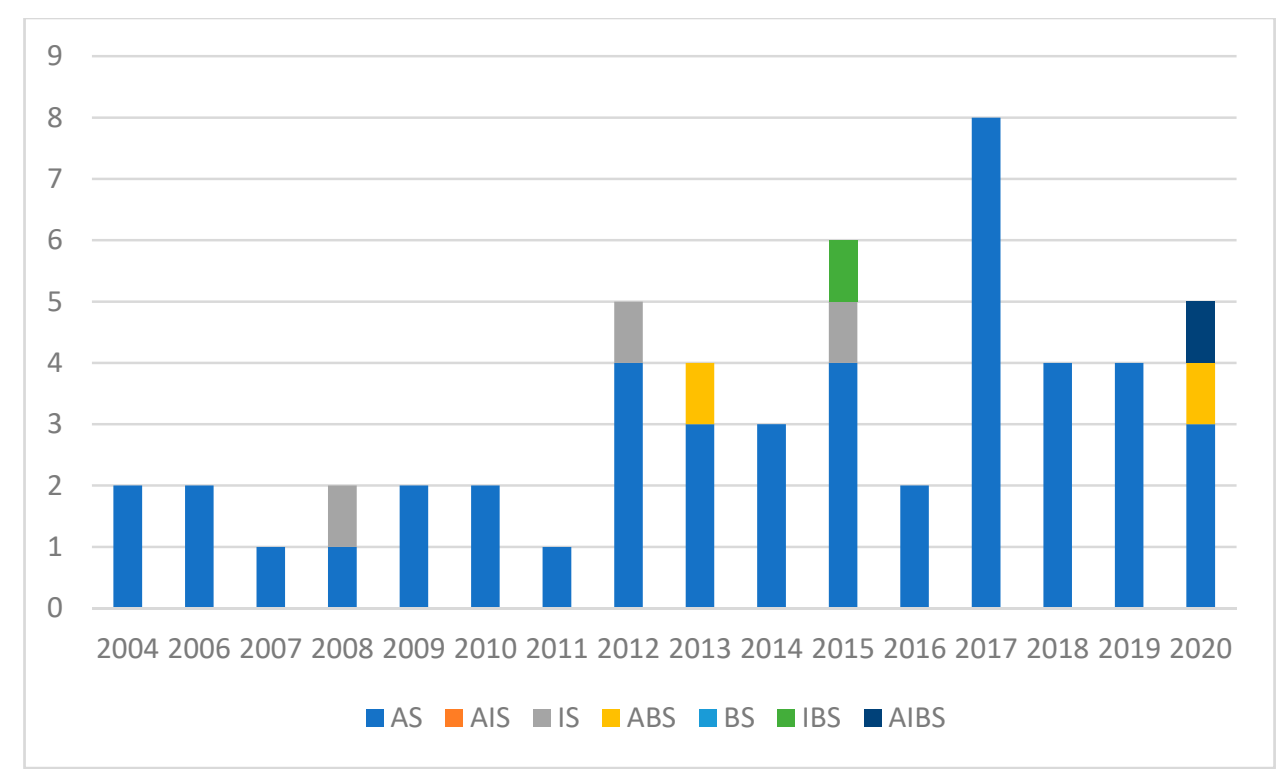

Figure 4. Summary of the type of residents's support dimensions in research by years. Source: elaborated by the authors. AS: Attitudinal Support; AIS: Attitudinal and Intentional Support; IS: Intentional Support; ABS: Attitudinal and Behavioral Support; BS: Behavioral Support; IBS: Intentional and Behavioral Support; AIBS: Attitudinal, Intentional, and Behavioral Support. Source: elaborated by the authors.

An initial observation reveals a constant feature in resident studies, namely the use of the variable of support as a synonym of the "attitude of the resident towards tourism" ("attitudinal support" in the proposed terminology). Specifically, $86.8 \%$ of the articles analyzed exclusively link the concept of support to the attitudinal dimension, while $7.5 \%$ measure it with items that exclusively refer to the intentional dimension, and none of them measure behavior. In spite of the comprehensive nature of the concept of support, this demonstrates that the majority of the articles are centered around the analysis of a single dimension of the concept (94.3\%), essentially focusing on the attitudes $(86.8 \%)$ as opposed to intentions (5.7\%), and that the area of behavior in not addressed in any case.

The sparse use of the term "support" exclusively associated with intention does not present a clear trend over time. On the contrary, it is homogeneously spread throughout the period under study, which shows that at no point does the concept leave the field of attitude to move on to that of intentions, and much less that of behavior, which is not addressed in any case.

The construct of support seeks to cover two or more of its potential dimensions simultaneously in only three articles (5.7\%). In addition, the following comments are made on each of them: 
Lee (2013) [74] defined the latent variable "support for sustainable tourism development" on the basis of an item related to the attitudinal aspect ("I support the development of community-based sustainable tourism initiatives") and another four items that reflect clear behavioral components related to participation and cooperation ("I participate in sustainable tourism-related plans and development", "I participate in cultural exchanges between local residents and visitors", "I cooperate with tourism planning and development initiatives", and "I participate in the promotion of environmental education and conservation").

Two years later, Zhou et al. (2015) [75] addressed the construct of "support for tourism", combining intentional ("I am willing to support tourism development") and behavioral ("I want to continue to participate in tourism or will to participate in the future") aspects.

Finally, Ritchie et al. (2020) [76] recently addressed the construct of "future event support" using items that cover the three dimensions of support, i.e., the attitudinal dimension ("residents were asked to indicate their overall support for hosting the 2012 Olympic events and associated development"), the intentional dimension ("please indicate the probability that you would support the hosting of future events"), and the behavioral dimension ("Did you visit any of the following events/places in Weymouth and Portland during the Games?", "Did you volunteer as a Weymouth and Portland ambassador or a Games maker during London 2012?").

If we look at the years in which these studies were published, it can be concluded that the use of items that combine different dimensions of the concept of support is a phenomenon that is confined to the second half of the analyzed period and that may be partially due to two aspects: (a) the greatest number of research endeavors pertaining to resident support identified in this second half (accounting for $68.5 \%$ of the analyzed articles); and (b) the recent addition to the field of resident studies of theoretical frameworks that complement the traditional SET and attempt to go beyond the knowledge of resident attitudes to explore their intentions and behaviors with respect to tourism development (the introduction of TRA from the psychological field into the domains of tourism research is a clear example of this).

Tables A2-A4 (see Appendix B) classify the articles pursuant to the support dimensions set out in the conceptual model and list the set of items used to measure the support variable. The analysis of these tables produces results in terms of the terminology used to measure each of the three support dimensions, and they serve as a reference for researchers in the selection of items to configure the variable.

As shown in Table 1, the most commonly used word among the 51 constructs analyzed containing items related to attitudes is "support". This word appears in 35 out of the 51 constructs $(68.7 \%)$. This is another indication of the confusion surrounding the terminology related to this object of study. This word is followed by statements made by residents about what, in their opinion, tourism can entail for their locality - be it opinions, beliefs, desires, etc. In fact, these expressions appear in 19 of these 51 constructs $(37.3 \%)$. Other expressions that constitute items related to attitude make reference to statements about the role of the government in the tourism development in the locality, appearing in 14 out of the 51 constructs (27.5\%). Finally, a large part of the items are constructed with expressions that contain the following verbs: "I believe ... " (21.6\%), "I am proud ... " (11.9\%), "I am happy ... " $(7.9 \%)$, "I am glad ... " (7.9\%), "I'd like ... " (5.9\%), "I am in favor ... " (3.9\%), "I hope ... " (3.9\%), "I am excited about ... " (2\%), "My attitude about ... " (2\%), "I perceive ... " (2\%).

Furthermore, the expressions that appear most frequently, in $50 \%$ of the constructs, in the 6 constructs containing items related to the intentional dimension of support are as follows: "I would support ..." and "I will ...," with the latter appearing in the following verbal forms: "I would be willing," "I will join," and "I am willing." Finally, the following appear among the different items: "I need to ...," "I want to ..., ," and "I should...," with each one of these contributing to the formation of a construct $(16.67 \%)$.

Ultimately, the following stands out among the items that contribute towards measuring the dimension of support related to behaviors: "I participate ....," "I cooperate ... .," "I visited ...," 
"I want to continue ...," and "I was a volunteer." All of these appear in just one of the three constructs identified in this support dimension, as few studies address the analysis of this dimension.

In summary, in light of the many items used in the evaluation of the three conceptual dimensions of support, the following expressions are most commonly used.

\section{Conclusions}

Over the last fifteen years, there has been an increase in the number of studies on the concept of "residents' support" published in the three tourism journals with the greatest impact in the Journal Citation Index (JCR 2018) [62] due to the increasing importance of the role that residents play in implementing tourism development processes.

This growing number of studies on residents' support requires a homogeneous methodology in order to draw comparisons between them, something touched upon by Boley and Strzelecka (2016) [7], in view of the lack of standardization of the scales used to measure the attitudes of residents towards tourism development in their localities. The problem is compounded further when the attitudinal dimension of support ceases to be unique and reaches the field of intentions and behaviors, including a variety of items in the composition of the same latent variable.

Both aspects are clearly reflected in the results of this study, which reveal the indisputable prominence of the attitudinal facet in providing semantic content to the concept of support, perhaps conditioned by the clear hegemony that SET has had and continues to have within the theoretical framework of resident studies. In fact, for many years the final objective of the majority of studies on residents has been to identify and explain the attitudes of residents towards tourism in their locality, analyzing the variables that influence them.

However, in recent years new theoretical frameworks have emerged which have sought to complement SET and move beyond perceptions and attitudes of residents to focus on their intentions and behaviors. This phenomenon has coincided with a paradigm shift in that the resident is no longer analyzed as a passive subject that endures or benefits from tourism development in his/her locality and has become an active agent that can favor or hinder the future of tourism in a region with his/her actions.

Accompanying this paradigm shift, new theories have escaped the strict psychological domain where they emerged to branch into new and complex phenomena, including tourism. One of the fundamental theories that has facilitated progress in resident studies in recent years is the TRA. The advantage of this theory is that it considers the attitudinal, intentional, and behavioral dimensions to be distinct and interrelated latent variables, which provides an innovative framework for future support studies to focus on their study without the need to incorporate items from each of these dimensions in the composition of each unique construct, as done previously by some of the articles analyzed.

The use of standardized terminology in accordance with the conceptual model presented in Figure 2 (irrespective of the dimensions of the support concept to be analyzed) would very much favor the comparison of studies. It would also be advisable to conduct studies that simultaneously include all the conceptual dimensions defined in Figure 1, albeit in separate constructs. From a theoretical and qualitative perspective, this study seeks to initiate a process of debate and reflection on the characterization and conceptualization of the items that should be used to develop the construct of "residents' support" in its different attitudinal, intentional, and behavioral dimensions.

A series of expressions are recommended for the wording of the items of the construct. In the case of attitudinal support (AS), these construct items could use verbs such as "I believe," "I think," or "I would like." For intentional support (IS), these could be "I will," "I need," or "I am going to." And for behavioral support (BS) these could be "I participate," "I cooperate," and "I visited."

As regards the implications of this study for scholars, there are two points to be made: (a) There is a need to advance in the analysis of residents' support for tourism development and attempt to standardize the terminology used in the research. To do this, it is necessary to consistently clarify the dimension or dimensions of the support to be addressed and to be very clear about the 
items to be used to create the constructs of each of these dimensions, and (b) There is a need to advance in the analysis of residents' intentions and, above all, behavior, and to delve deeper into the attitude-intention-behavior sequence.

On the other hand, the analysis of the concept of residents' support, broken down into its different dimensions, will help entrepreneurs and public authorities in the destination to determine more thoroughly the role that the different groups and segments of the local population can play in promoting sustainable tourism development processes. To this effect, some studies have shown that attitudes are weakly associated with behavior [38] (Krosnick and Richard, 1995) and behavior is influenced by more variables than just attitudes [39] (Azjen and Fishbein, 1980).

This study does, however, have several limitations. The first of these arises from the extended literature review, centered on articles published in the three most prestigious journals in the tourism field over a time period of fifteen years (2004 to first quarter of 2020).

In spite of these limitations, this study can be regarded as a reasonable starting point, from a conceptual and terminological perspective, to delve into other relevant issues, such as the validity of the items used to shape the support construct, as carried out in [7] Boley and Strzelecka (2016).

As future lines of research, it would be advisable to standardize the assessment scales used to quantify the different items that constitute each of the constructs. This would enable us to compare the findings of studies, in addition to their conclusions.

Furthermore, the preparation of empirical studies to create and test items and measurement scales for each of the dimensions of the support concept, the analysis of the actual interrelations that can arise between the different dimensions, and the classification of residents according to the different support dimensions are all areas of research to be pursued as a result of this study.

The literature and analysis are now focused almost exclusively on resident support in tourism. There are however other fields (e.g., urban development) where resident support is also analyzed. It would be worth investigating whether or not these fields suffer from the same ambiguity regarding the usage of the term, or if there is more consistency there. It also would be of interest to find out if there is a relationship between the context of the study and the way the concept of residents' support is defined/applied.

In applying the Theory of Reasoned Action to build the theoretical framework, this article focuses very much on the sequence attitude-intention-behavior. Although there is a logic in applying this simplified version of the TRA theory, given the arguments that studies should be directed at closing the attitude-behavior gap, it does raise the question if a different theoretical base (focused less on the step towards behavior and, e.g., more on the way attitudes are formed) would have lead to a different subdivision of the dimensions of residents' support. Given the large number of revised papers focused on the attitudinal support dimension, added value can perhaps be achieved by introducing a further differentiation of the concept of attitude by including the concepts of "Evaluation of Behavioral Outcomes" and "Behavioral Beliefs" (specified in TRA).

Author Contributions: Conceptualization and methodology, M.Á.P.-M., N.P.-B. and D.F.-R.; validation, M.Á.P.-M. and N.P.-B.; investigation, resources, data curation and writing-original draft preparation, M.Á.P.-M., N.P.-B. and D.F.-R.; writing-review and editing, M.Á.P.-M.; visualization, M.Á.P.-M., N.P.-B. and D.F.-R.; supervision, M.Á.P.-M. and N.P.-B. All authors have read and agreed to the published version of the manuscript.

Funding: This research received no external funding.

Conflicts of Interest: The authors declare no conflict of interest. 


\section{Appendix A}

Table A1. "resident's support" research review. Source: Authors.

\begin{tabular}{|c|c|c|c|c|c|c|c|c|}
\hline \multirow{2}{*}{ Year } & \multirow{2}{*}{ Author/s } & \multirow{2}{*}{ Theory } & \multirow{2}{*}{ Methodology } & \multirow{2}{*}{ Sitting of Study } & \multirow{2}{*}{ Name of "Support" Construct } & \multicolumn{3}{|c|}{ Items Related to ... } \\
\hline & & & & & & Attitude & Intention & Behavior \\
\hline 2004 & Gursoy and Rutherford [16] & SET & CB-SEM & $\begin{array}{c}\text { Selected counties of } \\
\text { Washington and Idaho } \\
\text { (USA) }\end{array}$ & $\begin{array}{c}\text { Community support for tourism } \\
\text { development }\end{array}$ & $x$ & & \\
\hline 2004 & McGehee and Andereck [77] & SET & MRA & Arizona (USA) & $\begin{array}{l}\text { Support for additional tourism } \\
\text { Support for tourism planning }\end{array}$ & $x$ & & \\
\hline 2006 & Gursoy and Kendall [31] & SET & CB-SEM & $\begin{array}{l}\text { Salt Lake City, Utah, } \\
\text { (USA) }\end{array}$ & Support for mega events & $x$ & & \\
\hline 2006 & Lee \& Back [78] & SET, SCCT & CB-SEM & South Korea & Support & $x$ & & \\
\hline 2007 & $\begin{array}{l}\text { Dyer, Gursoy, Sharma, } \\
\text { and Carter [33] }\end{array}$ & SET, TRA & $\begin{array}{l}\text { EFA, CB-SEM, } \\
\text { CFA }\end{array}$ & Queensland (Australia) & Support for tourism & $x$ & & \\
\hline 2008 & $\begin{array}{l}\text { Kang, Lee, Yoon, } \\
\text { and Long [79] }\end{array}$ & SET & $\begin{array}{l}\text { EFA, CB-SEM, } \\
\text { CFA }\end{array}$ & Colorado (USA) & $\begin{array}{l}\text { Support for community } \\
\text { development }\end{array}$ & & $x$ & \\
\hline 2008 & Wang and Pfister [80] & SET & LSRA & North Carolina (USA) & Support for tourism development & $x$ & & \\
\hline 2009 & $\begin{array}{l}\text { Draper, Woosnam, } \\
\text { and Norman [81] }\end{array}$ & TUH & ANCOVA & $\begin{array}{l}\text { Beaufort and Oconee } \\
\text { counties, South } \\
\text { Carolina (USA) }\end{array}$ & Government support & $x$ & & \\
\hline 2009 & Nicholas, Thapa, and Ko [82] & ST & CB-SEM & $\begin{array}{l}\text { Santa Lucia Island } \\
\text { (Caribbean). }\end{array}$ & $\begin{array}{c}\text { Support for sustainable tourism } \\
\text { development } \\
\text { Support for PMA as World } \\
\text { Heritage Site }\end{array}$ & $\mathrm{x}$ & & \\
\hline 2010 & Gursoy, Chi, and Dyer [15] & SET & CB-SEM & $\begin{array}{l}\text { Sunshine Coast } \\
\text { (Australia) }\end{array}$ & $\begin{array}{l}\text { Community support or opposition } \\
\text { for conventional mass tourism } \\
\text { development; Community support } \\
\text { or opposition for alternative } \\
\text { tourism development }\end{array}$ & $\mathrm{x}$ & & \\
\hline 2010 & $\begin{array}{l}\text { Lee, Kang, Long, and } \\
\text { Reisinger [83] }\end{array}$ & SET & PCA, MRA & $\begin{array}{l}\text { Gamgwon (Korea) and } \\
\text { Colorado (USA) }\end{array}$ & Support & $x$ & & \\
\hline 2011 & $\begin{array}{l}\text { Nunkoo and } \\
\text { Ramkissoon [20] }\end{array}$ & SET & CB-SEM & Grand-Baie, (Mauritius) & Support for tourism development & $x$ & & \\
\hline 2012 & $\begin{array}{l}\text { Chien, Ritchie, Shipway, } \\
\text { and Henderson [84] }\end{array}$ & SET, FHT, SDT & MRA & London (UK) & $\begin{array}{c}\text { Residents' intention to support the } \\
\text { event }\end{array}$ & & $x$ & \\
\hline 2012 & Látková and Vogt [85] & SET, DLC & MRA & $\begin{array}{c}\text { Rural areas in a } \\
\text { Midwest state (USA) }\end{array}$ & $\begin{array}{l}\text { Support for future tourism } \\
\text { development }\end{array}$ & $x$ & & \\
\hline 2012 & Nunkoo and Gursoy [18] & SET, PIT & CB-SEM & Mauritius & Support for tourism & $x$ & & \\
\hline
\end{tabular}


Table A1. Cont.

\begin{tabular}{|c|c|c|c|c|c|c|c|c|}
\hline \multirow{2}{*}{ Year } & \multirow{2}{*}{ Author/s } & \multirow{2}{*}{ Theory } & \multirow{2}{*}{ Methodology } & \multirow{2}{*}{ Sitting of Study } & \multirow{2}{*}{ Name of "Support" Construct } & \multicolumn{3}{|c|}{ Items Related to ... } \\
\hline & & & & & & Attitude & Intention & Behavior \\
\hline 2012 & $\begin{array}{c}\text { Nunkoo and } \\
\text { Ramkissoon [86] }\end{array}$ & SET & CB-SEM & Mauritius & Political support for tourism & $x$ & & \\
\hline 2012 & Woosnam [87] & ES, SET & CB-SEM & $\begin{array}{l}\text { Galveston County, } \\
\text { Texas (USA) }\end{array}$ & Support for tourism development & $\mathrm{x}$ & & \\
\hline 2013 & Kaplanidou et al. [88] & SET & MAC, PAM & $\begin{array}{c}\text { Rustenburg, } \\
\text { Johannesburg, Pretoria, } \\
\text { Nelspruit, and } \\
\text { Polokwane (South } \\
\text { Africa) }\end{array}$ & $\begin{array}{l}\text { Event support for the } 2010 \text { FIFA } \\
\text { World Cup (Pre- and Post-Event) }\end{array}$ & $x$ & & \\
\hline 2013 & Lee [74] & CA, SET & CFA, CB-SEM & Cigu wetland (Taiwan) & $\begin{array}{l}\text { Support for sustainable tourism } \\
\text { development }\end{array}$ & $X$ & & $x$ \\
\hline 2013 & Nunkoo and Smith [21] & SET & CFA, CB-SEM & $\begin{array}{l}\text { Niagara Region } \\
\text { (Ontario, Canadá) }\end{array}$ & Political support for tourism & $x$ & & \\
\hline 2013 & $\begin{array}{l}\text { Prayag, Hosany, Nunkoo, } \\
\text { and Alders [9] }\end{array}$ & SET, TRA & PLS-SEM & London (UK) & Support for the games & $\mathrm{x}$ & & \\
\hline 2014 & $\begin{array}{l}\text { Boley, McGehee, Perdue, } \\
\text { and Long [89] }\end{array}$ & WT; SET & CB-SEM, CFA & $\begin{array}{l}\text { Floyd, Botetourt, and } \\
\text { Franklin County, } \\
\text { Virginia (USA) }\end{array}$ & Support for Tourism & $\mathrm{x}$ & & \\
\hline 2014 & $\begin{array}{l}\text { Stylidis, Biran, Sit, } \\
\text { and Szivas [90] }\end{array}$ & SET & EFA, CB-SEM & Kavala (Greece) & Support for tourism development & $x$ & & \\
\hline 2014 & Stylidis and Terzidou [91] & SET & CB-SEM & Kavala (Grecia) & Support for tourism & $x$ & & \\
\hline 2015 & $\begin{array}{l}\text { Jaafar, Noor, and } \\
\text { Rasoolimanesh [92] }\end{array}$ & ST, SET & PLS-SEM & Lennggong (Malaysia) & $\begin{array}{l}\text { Involvement in promoting and } \\
\text { supporting world heritage sites }\end{array}$ & & $\mathrm{x}$ & \\
\hline 2015 & Sinclair-Maragh, Gursoy [93] & IT & MRA & Jamaica & Tourism support & $X$ & & \\
\hline 2015 & Wang and Chen [94] & SET, PIT & CB-SEM & Indianapolis (USA) & $\begin{array}{l}\text { Attitudes toward support for } \\
\text { tourism }\end{array}$ & $x$ & & \\
\hline 2015 & Wang and $\mathrm{Xu}[95]$ & SET, PIT & CB-SEM, CFA & Zhuhai (China) & $\begin{array}{l}\text { Attitudes towards support for } \\
\text { tourism }\end{array}$ & $x$ & & \\
\hline 2015 & Woo, Kim, and Uysal [96] & SET & CB-SEM & $\begin{array}{c}\text { Virginia, Hawaii, Las } \\
\text { Vegas, } \\
\text { Orlando. (USA) }\end{array}$ & $\begin{array}{c}\text { Support for further tourism } \\
\text { development }\end{array}$ & $x$ & & \\
\hline 2015 & $\begin{array}{l}\text { Zhou, Zhang, Zhang, } \\
\text { and Ma [75] }\end{array}$ & SET, AP & CB-SEM, CFA & $\begin{array}{l}\text { Jiuzhai Valley, in } \\
\text { Northern } \\
\text { Sichuan (China) }\end{array}$ & Support for tourism & & $x$ & $x$ \\
\hline 2016 & Liang and Hui [97] & QL & EFA, MRA, C & Shenzhen (China) & $\begin{array}{l}\text { Support for future tourism } \\
\text { development }\end{array}$ & $x$ & & \\
\hline
\end{tabular}


Table A1. Cont.

\begin{tabular}{|c|c|c|c|c|c|c|c|c|}
\hline \multirow{2}{*}{ Year } & \multirow{2}{*}{ Author/s } & \multirow{2}{*}{ Theory } & \multirow{2}{*}{ Methodology } & \multirow{2}{*}{ Sitting of Study } & \multirow{2}{*}{ Name of "Support" Construct } & \multicolumn{3}{|c|}{ Items Related to ... } \\
\hline & & & & & & Attitude & Intention & Behavior \\
\hline 2016 & Nunkoo and So [98] & SET & CB-SEM & $\begin{array}{l}\text { The Niagara Region } \\
\text { (Canada) }\end{array}$ & Support for tourism & $x$ & & \\
\hline 2017 & Al-Emadi et al. [99] & SET & MRA & Qatar & Support for the 2022 World Cup & $x$ & & \\
\hline 2017 & Chi, Cai, and Li [100] & SET, SWB & CFA, CB-SEM & Lijang (China) & Support for tourism & $x$ & & \\
\hline 2017 & $\begin{array}{l}\text { Gursoy, Yolal, Ribeiro, and } \\
\text { Panosso Netto [101] }\end{array}$ & SET & CB-SEM & $\begin{array}{l}12 \text { host cities of the } 2014 \\
\text { FIFA World Cup } \\
\text { (Brazil) }\end{array}$ & Support for mega-events & $x$ & & \\
\hline 2017 & $\begin{array}{c}\text { Moghavvemi, Woosnam, } \\
\text { Paranamathan, Musa, and } \\
\text { Hamzah [102] }\end{array}$ & SET, TRA & CB-SEM & Malaysia & Support & $\mathrm{x}$ & & \\
\hline 2017 & Olya and Gavilyan [103] & $\mathrm{CT}$ & QCA & Hawraman (Iran) & Support for tourism development & $x$ & & \\
\hline 2017 & $\begin{array}{l}\text { Ouyang, Gursoy, } \\
\text { and Sharma [104] }\end{array}$ & SET, CAT & MRA & $\begin{array}{l}12 \text { host } \\
\text { cities for the } 2014 \text { FIFA } \\
\text { World Cup in Brazil }\end{array}$ & Support for hosting a mega-event & $x$ & & \\
\hline 2017 & $\begin{array}{l}\text { Rasoolimanesh, Ringle, } \\
\text { Jaafar, and Ramayah [105] }\end{array}$ & SET & PLS-SEM & $\begin{array}{l}\text { George Town and } \\
\text { Lenggong (Malaysia) }\end{array}$ & Support for tourism development & $x$ & & \\
\hline 2017 & Zuo, Gursoy, and Wall [106] & FSR & CB-SEM & China & Support for red tourism in China & $x$ & & \\
\hline 2018 & $\begin{array}{c}\text { Boley, Strzelecka, and Watson } \\
{[14]}\end{array}$ & RE, WT & CB-SEM & Rural areas (Poland) & Support for tourism & $x$ & & \\
\hline 2018 & Chi, Ouyang, and Xu [107] & SET & CB-SEM & $\begin{array}{c}\text { Brazil } \\
\text { Taebaek City (USA) and }\end{array}$ & Support for the mega-event & $X$ & & \\
\hline 2018 & Lee, Kim, and Kim [108] & ST, SET & SOFA, CB-SEM & $\begin{array}{l}\text { Jeongsum County } \\
\text { (South Korea) }\end{array}$ & Support & $x$ & & \\
\hline 2018 & $\begin{array}{l}\text { Woosnam, Draper, Jiang, } \\
\text { Aleshinloye, and Erul [109] }\end{array}$ & SP & $\begin{array}{c}\text { ANCOVA, } \\
\text { ANOVA, CFA }\end{array}$ & $\begin{array}{l}\text { Galventon, Houston } \\
\text { (Texas) }\end{array}$ & Support for tourism development & $x$ & & \\
\hline 2019 & $\begin{array}{c}\text { Garau-Vadell, } \\
\text { Gutiérrez-Taño, and } \\
\text { Díaz-Armas [110] }\end{array}$ & SET & PLS-SEM & $\begin{array}{l}\text { Tenerife-Canary Islands } \\
\text { (Spain) }\end{array}$ & $\begin{array}{l}\text { Support for peer-to-peer } \\
\text { accommodation }\end{array}$ & $x$ & & \\
\hline 2019 & $\begin{array}{l}\text { Kock, Josiassen, Assaf, } \\
\text { Karpen, and Farrelly [111] }\end{array}$ & AT & CB-SEM & $\begin{array}{l}\text { US respondents } \\
\text { recruited from the } \\
\text { Mechanical Turk online } \\
\text { panel }\end{array}$ & $\begin{array}{l}\text { Residents' support for tourism } \\
\text { development } \\
\text { Perceived support of fellow } \\
\text { tourists }\end{array}$ & $\mathrm{x}$ & & \\
\hline
\end{tabular}


Table A1. Cont.

\begin{tabular}{|c|c|c|c|c|c|c|c|c|}
\hline \multirow{2}{*}{ Year } & \multirow{2}{*}{ Author/s } & \multirow{2}{*}{ Theory } & \multirow{2}{*}{ Methodology } & \multirow{2}{*}{ Sitting of Study } & \multirow{2}{*}{ Name of "Support" Construct } & \multicolumn{3}{|c|}{ Items Related to ... } \\
\hline & & & & & & Attitude & Intention & Behavior \\
\hline 2019 & $\begin{array}{l}\text { Ouyang, Gursoy, } \\
\text { and Chen [112] }\end{array}$ & QL & MET & Hong Kong (China) & Support towards events & $x$ & & \\
\hline 2019 & $\begin{array}{l}\text { Papastathopoulos, Ahmad, } \\
\text { Al Sabri, and Kaminakis [113] }\end{array}$ & SET & B-SEM & $\begin{array}{l}\text { Abu Dhabi and Dubai } \\
\text { (UAE) }\end{array}$ & Support for tourism development & $\mathrm{x}$ & & \\
\hline 2020 & $\begin{array}{c}\text { Gannon, Rasoolimanesh, and } \\
\text { Taheri [114] }\end{array}$ & SET, WT & PLS-SEM & $\begin{array}{l}\text { Kashan and Tabriz } \\
\text { (Irán) }\end{array}$ & Support for tourism development & $x$ & & \\
\hline 2020 & $\begin{array}{l}\text { Kanwal, Rasheed, Pitafi, } \\
\text { Pitafi, \& Ren [115] }\end{array}$ & SET & CFA, CB-SEM & $\begin{array}{c}\text { Gilgit Baltistan and } \\
\text { KPK } \\
\text { (Pakistan). }\end{array}$ & Community support for tourism & $x$ & & \\
\hline 2020 & $\begin{array}{l}\text { Ritchie, Chien, } \\
\text { and Shipway [76] }\end{array}$ & SET & $\begin{array}{l}\text { MANCOVA, } \\
\text { MRA }\end{array}$ & $\begin{array}{l}\text { Borough of Weymouth } \\
\text { and Portland (England) }\end{array}$ & Future event support & $x$ & $\mathrm{x}$ & $x$ \\
\hline 2020 & $\begin{array}{l}\text { Suess, Woosnam, } \\
\text { and Erula [1] }\end{array}$ & ES, PMT & CFA, CB-SEM & $\begin{array}{l}\text { A large panel of } \\
\text { nonhosting } \\
\text { residents who } \\
\text { confirmed }\end{array}$ & Support for Airbnb & $x$ & & \\
\hline 2020 & $\begin{array}{c}\text { Yeager, Boley, } \\
\text { Woosnam and Green [116] }\end{array}$ & SET, WT & CFA, CB-SEM & $\begin{array}{c}\text { Savannah, } \\
\text { Georgia (United States) }\end{array}$ & $\begin{array}{l}\text { Support for short-term vacation } \\
\text { rentals (STVRs) }\end{array}$ & $x$ & & \\
\hline
\end{tabular}

THEORY: AA: Attitudinal ambivalence; AT: Attitude Theory; BS: Bottom-up Spillover Theory; B-SEM: Bayesian SEM; CA: Community Attachment; CAT: Cognitive Appraisal Theory; CT: Complexity theory; ES: Emotional Solidarity; ET: Experience-based Theory; DLC: Destination Life Cycle; FHT: Fairness Heuristic Theory; FSR: Theory of Formal and Substantive Rationality; IT: Institutional Theory; MET: Means-End Theory; NBT: Negativity Bias Theory; PMT: Protection Motivation Theory; PIT: Place Identity Theory; QL: Quality of Life; RE: Resident Empowerment; RETS: Resident Empowerment through Tourism Scale; SCCT: Social Carrying Capacity Theory; SDT: Social Dilemma Theory; SET: Social Exchange Theory; SP: Self Perception Theory; ST: Stakeholder Theory; SWB: Subjective Well-being; TRA: Theory of Reasoned Action; TUH: Tourism Use History; WT: Weber's Theory of Substantive and Formal rationality; CS: Community Support; AP: Authenticity Perception. METHODOLOGY: ANCOVA: Analysis of the Covariance; ANOVA: Variance Analysis; C: Cluster; CB-SEM: Covariance-Based Structural Equation Model; CFA: Confirmatory Factor Analysis; EFA: Exploratory Factor Analysis; LSRA: Least Squares Regression Analysis; MAC: Multivariate Analysis of Covariance; MANCOVA: Multivariate Analysis of Covariance; MRA: Multiple Regression Analysis; PAM: Path Analysis Model; PC: Pearson Correlations; PCA: Principal component analyses; PLS-SEM: Partial Least Squares Structural Equation Model; QCA: Qualitative Comparative Analysis; SOFA: Second Order Factor Analyses. 


\section{Appendix B}

Table A2. Items used to measure Residents' Support from an attitudinal dimension: Source: Authors.

\begin{tabular}{|c|c|c|c|}
\hline Author/s & Year & Name of "Support" Variable & Attitudinal Items Used to Measure the Construct Support \\
\hline Gursoy and Rutherford & 2004 & $\begin{array}{l}\text { Community Support for } \\
\text { Tourism Development }\end{array}$ & $\begin{array}{l}\text { "How much you would oppose/support Nature based tourism development”; “How much you would } \\
\text { oppose/support Cultural or historic based attractions"; “How much you would oppose/support Nature } \\
\text { programs (such as guided nature walks)” }\end{array}$ \\
\hline McGehee and Andereck & 2004 & $\begin{array}{l}\text { Support for Additional Tourism } \\
\text { Support for Tourism Planning }\end{array}$ & $\begin{array}{l}\text { Support for additional tourism ("Tourism can be one of the most important industries for a community"; } \\
\text { "Additional tourism would help this community grow in the right direction"; “The tourism industry will } \\
\text { continue to (or could) play a major economic role in this community"; "I am happy and proud to see tourists } \\
\text { coming to see what my community has to offer"; "I support tourism having a vital role in this community"; } \\
\text { "Tourism holds great promise for my community's future"; “The tourism organization of my community's } \\
\text { government should do more to promote tourism"; "I favour building new tourism facilities which will attract } \\
\text { more tourists" }\end{array}$ \\
\hline & & & $\begin{array}{l}\text { Support for tourism planning (“My community should plan and manage the growth of tourism”) } \\
\text { "How much you would oppose or favor development of tourism services (for example; hotels; } \\
\text { restaurants)","How much you would oppose }\end{array}$ \\
\hline Gursoy and Kendall & 2006 & Support for Mega Events & $\begin{array}{c}\text { or favor development of information services for visitors (such as maps and guidebooks ", "How much you } \\
\text { would oppose }\end{array}$ \\
\hline Lee and Back & 2006 & Support & $\begin{array}{l}\text { or favor promotion of the area as a mega event destination (such as television advertising or brochures ... )" } \\
\text { "I believe the future of our city is bright due to the casino industry'; "I am proud that I live in this city"; "the } \\
\text { casino industry makes this city a better place to live"; "I support development of the casino"; "the } \\
\text { development of casino is the right choice for this city." }\end{array}$ \\
\hline $\begin{array}{c}\text { Dyer, Gursoy, Sharma, } \\
\text { and Carter }\end{array}$ & 2007 & Support for tourism & - \\
\hline Wang and Pfister & 2008 & $\begin{array}{l}\text { Support for tourism } \\
\text { development }\end{array}$ & $\begin{array}{l}\text { "I believe that tourism should be actively encouraged in my community"; "I support tourism and would like } \\
\text { to see it become an important part of my community"; "I am against new tourism facilities that will attract } \\
\text { more tourists to my community"; "I believe tourism should be actively encouraged in the State of North } \\
\text { Carolina"; "The city government was correct in supporting the promotion of tourism"; "Generally; the } \\
\text { positive benefits of tourism outweigh the negative impacts"; "My community should become more of a } \\
\text { tourist destination"; "Long-term planning by city officials can control the negative impacts of tourism on the } \\
\text { environment"; "Tourism has reduced the quality of outdoor recreation opportunities in my community"; "It is } \\
\text { important to develop plans to manage the growth of tourism"; "The tourism sector will continue to play a } \\
\text { major role in the economy of the community"; "One of the most important benefits of tourism is how it can } \\
\text { improve the local standard of living." }\end{array}$ \\
\hline $\begin{array}{l}\text { Draper, Woosnam, and } \\
\text { Norman }\end{array}$ & 2009 & Government support & $\begin{array}{c}\text { "County government should support local businesses serving tourists"; “County government should support } \\
\text { private business development in tourism." }\end{array}$ \\
\hline
\end{tabular}


Table A2. Cont.

\begin{tabular}{|c|c|c|c|}
\hline Author/s & Year & Name of "Support" Variable & Attitudinal Items Used to Measure the Construct Support \\
\hline Nicholas, Thapa, and Ko & 2009 & $\begin{array}{l}\text { Support for Sustainable } \\
\text { Tourism Development } \\
\text { Support for PMA as World } \\
\quad \text { Heritage Site }\end{array}$ & $\begin{array}{l}\text { "How much you would oppose/support development of community based tourism initiatives"; "How much } \\
\text { you would oppose/support local participation in tourism planning and development"; "How much you } \\
\text { would oppose/support cultural exchanges between local residents and visitors "; “How much you would } \\
\text { oppose/support cooperation and unity in tourism planning and development"; "How much you would } \\
\text { oppose/support regulatory environmental standards to reduce the negative impacts of tourism"; "How much } \\
\text { you would oppose/support promotion of environmental education and conservation" } \\
\text { "How much you would oppose/support the designation of the PMA as a UNESCO World Heritage Site"; } \\
\text { "How much you would oppose/support regulations and guidelines to maintain PMA as a UNESCO World } \\
\text { Heritage Site"; "How much you would oppose/support the promotion of the PMA as a UNESCO World } \\
\text { Heritage Site" }\end{array}$ \\
\hline Gursoy, Chi, and Dyer & 2010 & $\begin{array}{l}\text { Community support or } \\
\text { opposition for conventional } \\
\text { mass tourism development } \\
\text { Community support or } \\
\text { opposition for alternative } \\
\text { tourism development }\end{array}$ & 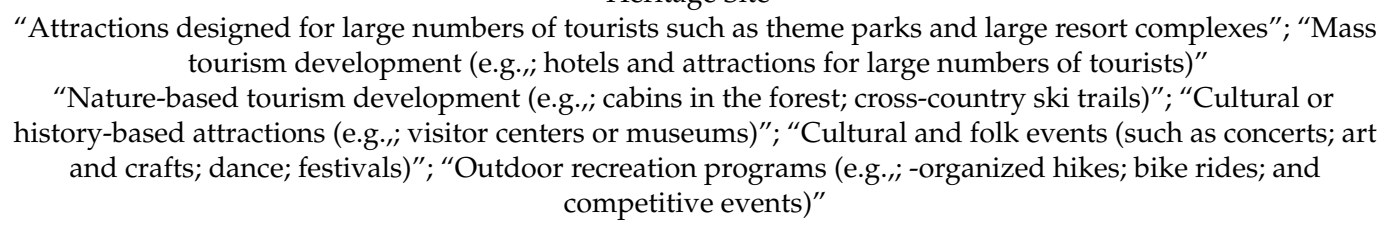 \\
\hline $\begin{array}{l}\text { Lee, Kang, Long, and } \\
\text { Reisinger }\end{array}$ & 2010 & Support & $\begin{array}{l}\text { "The casino development makes this community a better place to live"; "I am proud of living in a casino } \\
\text { town"; " The casino development is the right choice for my community"; "The future of my community looks } \\
\text { bright due to the casino development"; "I have supported the casino development in my community" }\end{array}$ \\
\hline Nunkoo and Ramkissoon & 2011 & $\begin{array}{l}\text { Support for tourism } \\
\text { development }\end{array}$ & $\begin{array}{c}\text { "Tourism can be one of the most important industries for my community"; "More tourism would help my } \\
\text { community grow in the right direction"; "Tourism industry will continue to play an important economic role } \\
\text { in your community"; "I am happy and proud that there are tourists coming to see what } \\
\text { my community has to offer" }\end{array}$ \\
\hline Látková and Vogt & 2012 & $\begin{array}{c}\text { Support for future tourism } \\
\text { development }\end{array}$ & $\begin{array}{c}\text { "Tourism can be one of the most important economic development options for an area"; "The county should } \\
\text { try to attract more tourists"; "Additional tourism would help the county grow in the right direction"; "I } \\
\text { support tourism having a vital role in this county" }\end{array}$ \\
\hline Nunkoo and Gursoy & 2012 & Support for tourism & $\begin{array}{l}\text { Level of support/opposition for different types of tourism development: "Small businesses"; "Cultural and } \\
\text { historic based attractions"; "All-inclusive forms of tourism development"; "Expansion in tourist arrivals to } 2 \\
\text { million tourists"; "Integrated resort projects" }\end{array}$ \\
\hline Nunkoo and Ramkissoon & 2012 & Political support for tourism & $\begin{array}{c}\text { "Tourism can be one of the most important industries for my community"; "More tourism would help the } \\
\text { economy to grow in the right direction"; "Tourism industry will continue to play an important economic role } \\
\text { in your community"; "I am happy and proud that there are tourists coming to see what } \\
\text { my community has to offer" }\end{array}$ \\
\hline Woosnam & 2012 & $\begin{array}{l}\text { Support for tourism } \\
\text { development }\end{array}$ & $\begin{array}{l}\text { "I support tourism and want to see it remain important to Galveston Co"; "I believe tourism should be } \\
\text { actively encouraged in Galveston Co."; "Galveston Co. should support the promotion of tourism"; "I support } \\
\text { new tourism facilities that will attract new visitors to Galveston Co"; "Galveston Co. should remain a tourist } \\
\text { destination"; "In general; the positive benefits of tourism outweigh negative impacts"; "The tourism sector } \\
\text { will continue to play a major role in the Galveston Co. economy"; "Long-term planning by Galveston Co. can } \\
\text { control negative environmental impacts"; "It is important to develop plans to manage the growth of tourism" }\end{array}$ \\
\hline
\end{tabular}


Table A2. Cont.

\begin{tabular}{|c|c|c|c|}
\hline Author/s & Year & Name of "Support" Variable & Attitudinal Items Used to Measure the Construct Support \\
\hline & & Event support for the 2010 FIFA & \\
\hline Kaplanidou et al. & 2013 & $\begin{array}{l}\text { World Cup (Pre- and } \\
\text { Post-Event) }\end{array}$ & "Overall I support(ed) the hosting of the World Cup in South Africa" \\
\hline Lee & 2013 & $\begin{array}{l}\text { Support for sustainable tourism } \\
\text { development }\end{array}$ & "I support the development of community-based sustainable tourism initiatives" \\
\hline Nunkoo and Smith & 2013 & Political support for tourism & $\begin{array}{l}\text { "“'How much you would oppose/support convention and meeting facilities"; “"How much you would } \\
\text { oppose/support Hotel development"; "“"How much you would oppose/support Casino development" }\end{array}$ \\
\hline $\begin{array}{l}\text { Prayag, Hosany, Nunkoo, } \\
\text { and Alders }\end{array}$ & 2013 & Support for the Games & “I support de 2012 Olympic Games as a resident"; “London should bid for other major sporting events" \\
\hline $\begin{array}{l}\text { Boley, McGehee, Perdue \& } \\
\text { Long }\end{array}$ & 2014 & Support for Tourism & $\begin{array}{l}\text { "In general; the positive benefits of tourism outweigh negative impacts in Floyd County"; "I believe tourism } \\
\text { should be actively encouraged in Floyd County"; "I support tourism and want to see it remain important to } \\
\text { Floyd County"; "Floyd County should remain a tourist destination"; "Floyd County should support the } \\
\text { promotion of tourism" }\end{array}$ \\
\hline $\begin{array}{l}\text { Stylidis, Biran, Sit, and } \\
\text { Szivas }\end{array}$ & 2014 & $\begin{array}{l}\text { Support for tourism } \\
\text { development }\end{array}$ & "Public finance for tourism promotion"; "Further tourism development"; "Increase in the number of tourists" \\
\hline Stylidis and Terzidou & 2014 & Support for tourism & $\begin{array}{l}\text { "Residents' general support for further tourism development"; "Residents' support for public funding of } \\
\text { tourism development"; "Residents' support for increasing the number of tourists to the city" }\end{array}$ \\
\hline Sinclair-Maragh, Gursoy & 2015 & Tourism Support & “I support tourism development' \\
\hline Wang and Chen & 2015 & $\begin{array}{l}\text { Attitudes toward support for } \\
\text { tourism }\end{array}$ & $\begin{array}{l}\text { Level of support (support/oppose) with "Small businesses"; "Cultural and historic based attractions"; } \\
\text { "All-inclusive forms of tourism development"; "Expansion in tourist arrivals to } 2 \text { million tourists"; } \\
\text { "Integrated resort projects" }\end{array}$ \\
\hline Wang and $\mathrm{Xu}$ & 2015 & $\begin{array}{l}\text { Attitudes towards support for } \\
\text { tourism }\end{array}$ & $\begin{array}{l}\text { "I'd like Zhuhai to attract more tourists"; "I'd like Zhuhai to add more culture-based attractions"; "Zhuhai } \\
\text { should invest more in developing tourism"; } \\
\text { "Local taxes should be used to Support Zhuhai's tourism development"; “The city should think of all types of } \\
\text { tourism development" }\end{array}$ \\
\hline Woo, Kim, and Uysal & 2015 & Support for further TD & $\begin{array}{c}\text { "Do you perceive the overall impact of tourism development in your community positively?"; "Would you } \\
\text { support tourism development in your } \\
\text { Community"; "Further tourism development would positively affect my community's quality of life" }\end{array}$ \\
\hline Liang and Hui & 2016 & $\begin{array}{l}\text { Support for future tourism } \\
\text { development }\end{array}$ & $\begin{array}{c}\text { "Tourism is important for community"; "Encourage tourism development in community"; ; Hope to attract } \\
\text { more visitors to community" }\end{array}$ \\
\hline Nunkoo and So & 2016 & Support for tourism & $\begin{array}{l}\text { "Tourism is one of the most important industries for my community"; "Tourism helps my community grow in } \\
\text { the right direction"; "I am proud that tourists are coming to my community"; "Tourism continues to play an } \\
\text { important economic role in my community"; "I support the development of tourism as it is vital to my } \\
\text { community"; "My community should attract more tourists" }\end{array}$ \\
\hline Al-Emadi et al. & 2017 & Support for the 2022 World Cup & "I support the FIFA decision to host the World Cup in Qatar" \\
\hline Chi, Cai, and Li & 2017 & Support for tourism & $\begin{array}{l}\text { "Lijiang should promote more cultural exchanges between local residents and tourists"; "I would like Lijiang } \\
\text { to attract more tourists"; "Lijiang should invest more in developing tourism"; "Local taxes should be used to } \\
\text { Support Lijiang's tourism development"; "The city should think of all types of tourism development" }\end{array}$ \\
\hline
\end{tabular}


Table A2. Cont.

\begin{tabular}{|c|c|c|c|}
\hline Author/s & Year & Name of "Support" Variable & Attitudinal Items Used to Measure the Construct Support \\
\hline $\begin{array}{l}\text { Gursoy, Yolal, Ribeiro, } \\
\text { and Panosso Netto }\end{array}$ & 2017 & Support for Mega-Events & $\begin{array}{c}\text { "I am glad that we are hosting the World Cup"; "I support Brazil hosting the World Cup"; "The idea of } \\
\text { hosting the World Cup gives me national pride" }\end{array}$ \\
\hline $\begin{array}{l}\text { Moghavvemi, Woosnam, } \\
\text { Paranamathan, Musa \& } \\
\text { Hamzah }\end{array}$ & 2017 & Support & $\begin{array}{l}\text { "Tourism can be one of the most important industries for a community "; "I Support the development of } \\
\text { community-based sustainable tourism initiatives"; "I support new tourism facilities that will attract new } \\
\text { tourists to my area/community"; "Additional tourism would help this community grow in the right } \\
\text { direction"; "I am happy and proud to see tourists are interested with what my community has to offer"; "I } \\
\text { believe tourism should be actively encouraged in my area/community". }\end{array}$ \\
\hline Olya and Gavilyan & 2017 & $\begin{array}{l}\text { Support for Tourism } \\
\text { Development }\end{array}$ & $\begin{array}{l}\text { "Tourism development is one of the most important Hawraman industries for my community"; "Tourism } \\
\text { helps my community grow in the right direction"; "I am glad that tourists are coming to my community"; } \\
\text { "Tourism continues to play an important economic role in my community"; "My community should attract } \\
\text { more tourists"; "Further tourism development would positively affect my community's quality of life"; "I } \\
\text { support the development of tourism; as it is vital to my community" }\end{array}$ \\
\hline $\begin{array}{l}\text { Ouyang, Gursoy, and } \\
\text { Sharma }\end{array}$ & 2017 & $\begin{array}{l}\text { Support for hosting a } \\
\text { mega-event }\end{array}$ & $\begin{array}{c}\text { "I am glad that we are hosting the World Cup"; "I support Brazil hosting the World Cup"; "The idea of } \\
\text { hosting the World Cup gives me national pride" }\end{array}$ \\
\hline $\begin{array}{l}\text { Rasoolimanesh, Ringle, } \\
\text { Jaafar, and Ramayah }\end{array}$ & 2017 & $\begin{array}{l}\text { Support for tourism } \\
\text { development }\end{array}$ & $\begin{array}{l}\text { "I believe that tourism should be actively encouraged in my community"; "I Support tourism and would like } \\
\text { to see it becomes an important part of my community"; "The local authorities and state government should } \\
\text { Support the promotion of tourism"; "Long-term planning by city officials can control the negative impacts of } \\
\text { tourism on the environment" }\end{array}$ \\
\hline Zuo, Gursoy, and Wall & 2017 & $\begin{array}{l}\text { Support for red tourism in } \\
\text { China }\end{array}$ & $\begin{array}{l}\text { "Most important industry for JGS"; “"Hope for more tourists"; “Support "red tourism" even if can't make } \\
\text { money"; "Support the promotion of "red tourism” }\end{array}$ \\
\hline $\begin{array}{l}\text { Boley, Strzelecka, and } \\
\text { Watson }\end{array}$ & 2018 & Support for Tourism & $\begin{array}{l}\text { "Tourism should be actively stimulated in our municipality"; "I support tourism and I want it to remain an } \\
\text { important element of municipality development"; "The municipality of Choczewo should remain a tourist } \\
\text { destination"; "The municipality should support promotion of tourism in Choczewo" }\end{array}$ \\
\hline Chi, Ouyang, and $\mathrm{Xu}$ & 2018 & Support for the mega-event & $\begin{array}{c}\text { "I am glad that we are hosting the World Cup"; "I support Brazil hosting the World Cup"; "The idea of } \\
\text { hosting the World Cup gives me national pride" }\end{array}$ \\
\hline Lee, Kim, and Kim & 2018 & Support & $\begin{array}{l}\text { "This gaming company's casino development is the right choice for this community"; "The future of this } \\
\text { community looks bright due to this gaming company's casino development"; "I support this gaming } \\
\text { company's casino development"; "This gaming company's casino development is desirable for this } \\
\text { community" }\end{array}$ \\
\hline $\begin{array}{l}\text { Woosnam, Draper, Jiang, } \\
\text { Aleshinloye, and Erul }\end{array}$ & 2018 & $\begin{array}{l}\text { Support for tourism } \\
\text { development }\end{array}$ & $\begin{array}{l}\text { "I support tourism and want to see it remain important too"; "I believe tourism should be actively } \\
\text { encouraged in Galveston"; “Galveston Co. should support the promotion of tourism"; "I support new } \\
\text { tourism facilities that will attract new visitors to Galveston"; "Galveston C. should remain a tourist } \\
\text { destination"; "In general; the positive benefits of tourism outweigh negative impacts"; “The tourism sector } \\
\text { will continue to play a major role in the Galveston Co. economy"; "Long-term planning by Galveston Co. can } \\
\text { control negative environmental impacts"; "It is important to develop plans to manage the growth of tourism" }\end{array}$ \\
\hline $\begin{array}{l}\text { Garau-Vadell, } \\
\text { Gutiérrez-Taño, and } \\
\text { Díaz-Armas }\end{array}$ & 2019 & $\begin{array}{l}\text { Support for peer-to-peer } \\
\text { accommodation }\end{array}$ & $\begin{array}{l}\text { "This form of accommodation is generally very positive for the island"; "This form of accommodation should } \\
\text { be more widely promoted"; "I am in favour of this form of accommodation"; "I like the fact that this type of } \\
\text { activity can be carried out" }\end{array}$ \\
\hline
\end{tabular}


Table A2. Cont.

\begin{tabular}{|c|c|c|c|}
\hline Author/s & Year & Name of "Support" Variable & Attitudinal Items Used to Measure the Construct Support \\
\hline $\begin{array}{l}\text { Kock, Josiassen, Assaf, } \\
\text { Karpen, and Farrelly }\end{array}$ & 2019 & $\begin{array}{l}\text { Residents' support for tourism } \\
\text { development } \\
\text { Perceived support of fellow } \\
\text { tourists }\end{array}$ & $\begin{array}{l}\text { "I support tourism development in our country"; "I am supportive of increasing tourism in our country"; } \\
\text { "The money invested to attract more tourists to our country is a good investment" } \\
\text { " Enough Americans support the domestic tourism industry" }\end{array}$ \\
\hline $\begin{array}{l}\text { Ouyang, Gursoy, and } \\
\text { Chen }\end{array}$ & 2019 & Support towards events & $\begin{array}{l}\text { "I am excited about Standard Chartered Marathon (SCMHK) 2018"; "I am glad about SCMHK 2018"; "I think } \\
\text { it is a wonderful idea to host SCMHK 2018" }\end{array}$ \\
\hline $\begin{array}{l}\text { Papastathopoulos, } \\
\text { Ahmad, Al Sabri, and } \\
\text { Kaminakis }\end{array}$ & 2019 & $\begin{array}{l}\text { Support for tourism } \\
\text { development }\end{array}$ & $\begin{array}{l}\text { "I think that the UAE should remain a tourist destination"; "The UAE should support the promotion of } \\
\text { tourism in the country"; "I believe tourism should be encouraged as a strategy for economic diversification for } \\
\text { the UAE"; "I believe that the overall impact of tourism in the UAE is positive". }\end{array}$ \\
\hline $\begin{array}{l}\text { Gannon, Rasoolimanesh, } \\
\text { and Taheri }\end{array}$ & 2020 & $\begin{array}{l}\text { Support for tourism } \\
\text { development }\end{array}$ & $\begin{array}{l}\text { "The residents should participate in tourism development conservation programs of heritage sites"; "I believe } \\
\text { that tourism should be actively encouraged in my community"; "I support tourism and would like to see it } \\
\text { become an important part of my community"; "The local authorities and state government should support } \\
\text { the promotion of tourism"; "It is important to develop plans to manage the conservation of historical sites and } \\
\text { growth of tourism". }\end{array}$ \\
\hline $\begin{array}{l}\text { Kanwal,, Rasheed, Pitafi, } \\
\text { Pitafi, and Ren }\end{array}$ & 2020 & $\begin{array}{l}\text { Community Support for } \\
\text { Tourism }\end{array}$ & $\begin{array}{l}\text { "CPEC should be developed"; "I believe that CPEC attracts more people to the area"; "I believe that CPEC } \\
\text { will play an important role for the economy of the area"; "I believe that Development of CPEC is vital to the } \\
\text { area"; "I believe that will help in establishing small business in the area such as travel agency, hotel, } \\
\text { restaurants, entertainment, etc.". }\end{array}$ \\
\hline $\begin{array}{l}\text { Ritchie, Chien, and } \\
\text { Shipway }\end{array}$ & 2020 & $\begin{array}{l}\text { Support the hosting of future } \\
\text { events }\end{array}$ & "My attitude towards the 2012 Games was Based"; "On your overall evaluations of the 2012 Games" \\
\hline Suess, Woosnam \& Erula. & 2020 & Support for Airbnb & "Visitors to your neighborhood"; "Airbnb hosts in your neighborhood" \\
\hline
\end{tabular}


Table A3. Items used to measure Residents' Support from an intentional dimension. Source: Authors.

\begin{tabular}{|c|c|c|c|}
\hline Author/s & Year & Name of "Support" Variable & Intentional Items Used to Measure the Construct Support \\
\hline Kang, Lee, Yoon, and Long & 2008 & Support for community development & $\begin{array}{l}\text { "I would do my best to enhance the development of my community"; "I would be } \\
\text { actively involved in community issues and activities"; "I would be willing to } \\
\text { provide financial support for the development of my community" }\end{array}$ \\
\hline $\begin{array}{l}\text { Chien, Ritchie, Shipway, and } \\
\text { Henderson }\end{array}$ & 2012 & Residents' intention to support the event & $\begin{array}{c}\text { Three-item asking residents the extent to which they would support the event's } \\
\text { development }\end{array}$ \\
\hline $\begin{array}{l}\text { Jaafar, Noor, and } \\
\text { Rasoolimanesh }\end{array}$ & 2015 & $\begin{array}{l}\text { Involvement in promoting and } \\
\text { supporting world heritage sites }\end{array}$ & $\begin{array}{l}\text { "I need to promote the archaeological sites as a villager in Lenggong"; "I want to } \\
\text { promote Lenggong by using posters; banner; leaflets; and so on"; "I will join those } \\
\text { activities which are relevant to the promotion of Lenggong" }\end{array}$ \\
\hline Zhou, Zhar & 2015 & & "I am willing to support tourism development" \\
\hline Ritchie, Chien, and Shipway & 2020 & Support the hosting of future events & indicate the probability that you would support the hosting of future events \\
\hline $\begin{array}{l}\text { Yeager, Boley, } \\
\text { Woosnam and Green }\end{array}$ & 2020 & $\begin{array}{l}\text { Support for short-term vacation rentals } \\
\text { (STVRs) }\end{array}$ & $\begin{array}{c}\text { "My neighborhood should actively encourage STVRs"; "My neighborhood should } \\
\text { support STVRs"; "My neighborhood should continue to allow STVRs"; "My } \\
\text { neighborhood should support the promotion of STVRs" }\end{array}$ \\
\hline
\end{tabular}

Table A4. Items used to measure Residents' Support from a behavioral dimension. Source: Authors.

\begin{tabular}{|c|c|c|c|}
\hline Author/s & Year & Name of "Support" Variable & Behavioral Items Used to Measure the Construct Support \\
\hline Lee & 2013 & $\begin{array}{c}\text { Support for sustainable tourism } \\
\text { development }\end{array}$ & $\begin{array}{c}\text { "I participate in sustainable tourism-related plans and development"; "I participate } \\
\text { in cultural exchanges between local residents and visitors"; "I cooperate with } \\
\text { tourism planning and development initiatives"; "I participate in the promotion of } \\
\text { environmental education and conservation" }\end{array}$ \\
\hline Zhou, Zhang, Zhang, and Ma & 2015 & Support for tourism & "I want to continue to participate in tourism or will participate in the future" \\
\hline Ritchie, Chien, and Shipway & 2020 & Support the hosting of future events & $\begin{array}{l}\text { "Did you visit any of the following events/places in Weymouth and Portland during } \\
\text { the Games?"; "Did you volunteer as a Weymouth and Portland ambassador or a } \\
\text { Games maker during London 2012?" }\end{array}$ \\
\hline
\end{tabular}




\section{References}

1. Suess, C.; Woosnam, K.M.; Erul, E. Stranger-danger? Understanding the Moderating Effects of Children in the Household on Non-Hosting Residents' Emotional Solidarity with Airbnb Visitors, Feeling Safe, and Support for Airbnb. Tour. Manag. 2020, 77, 103952. [CrossRef]

2. Harrill, R. Residents' Attitudes toward Tourism Development: A Literature Review with Implications for Tourism Planning. J. Plan. Lit. 2004, 18, 251-266. [CrossRef]

3. Deery, M.; Jago, L.; Fredline, L. Rethinking Social Impacts of Tourism Research: A New Research Agenda. Tour. Manag. 2012, 33, 64-73. [CrossRef]

4. Chen, S.C.; Raab, C. Predicting Resident Intentions to Support Community Tourism: Toward an Integration of Two Theories. J. Hosp. Mark. Manag. 2012, 21, 270-294. [CrossRef]

5. Nunkoo, R.; Smith, S.L.J.; Ramkissoon, H. Residents' Attitudes to Tourism: A Longitudinal Study of 140 Articles from 1984 to 2010. J. Sustain. Tour. 2013, 21, 5-25. [CrossRef]

6. Sharpley, R. Host Perceptions of Tourism: A Review of the Research. Tour. Manag. 2014, 42, 37-49. [CrossRef]

7. Boley, B.B.; Strzelecka, M. Towards a Universal Measure of "Support for Tourism”. Ann. Tour. Res. 2016, 61, 238-241. [CrossRef]

8. Gursoy, D.; Ouyang, Z.; Nunkoo, R.; Wei, W. Residents' Impact Perceptions of and Attitudes towards Tourism Development: A Meta-Analysis. J. Hosp. Mark. Manag. 2018, 1-28. [CrossRef]

9. Prayag, G.; Hosany, S.; Nunkoo, R.; Alders, T. London Residents' Support for the 2012 Olympic Games: The Mediating Effect of Overall Attitude. Tour. Manag. 2013, 36, 629-640. [CrossRef]

10. Carmichael, B. A Matrix Model for Resident Attitudes and Behaviours in a Rapidly Changing Tourist Area. Tour. Manag. 2000, 21, 601-611. [CrossRef]

11. Jackson, M.S.; Inbakaran, R.J. Evaluating Residents' Attitudes and Intentions to Act Towards Tourism Development in Regional Victoria, Australia. Int. J. Tour. Res. 2006, 8, 355-366. [CrossRef]

12. Oates, C.; McDonald, S. The Researcher Role in the Attitude-Behaviour Gap. Ann. Tour. Res. 2014, 46, 168-170. [CrossRef]

13. Juvan, E.; Dolnicar, S. The Attitude-Behaviour Gap in Sustainable Tourism. Ann. Tour. Res. 2014, 48, 76-95. [CrossRef]

14. Dolnicar, S. Why Quantitative Papers Based on Primary Data Get Desk-Rejected. Ann. Tour. Res. 2020, 60, 147-158.

15. Gursoy, D.; Chi, C.G.; Dyer, P. Locals' Attitudes Toward Mass and Alternative Tourism: The Case of Sunshine Coast, Australia. J. Travel Res. 2009, 49, 381-394. [CrossRef]

16. Gursoy, D.; Rutherford, D.G. Host Attitudes Toward Tourism. Ann. Tour. Res. 2004, 31, 495-516. [CrossRef]

17. Hasani, A.; Moghavvemi, S.; Hamzah, A. The Impact of Emotional Solidarity on Residents' Attitude and Tourism Development. PLoS ONE 2016, 11, e0157624. [CrossRef]

18. Nunkoo, R.; Gursoy, D. Residents' Support for Tourism: An Identity Perspective. Ann. Tour. Res. 2012, 39, 243-268. [CrossRef]

19. Nunkoo, R.; Ramkissoon, H. Residents' Satisfaction with Community Attributes and Support for Tourism. J. Hosp. Tour. Res. 2010, 35, 171-190. [CrossRef]

20. Nunkoo, R.; Ramkissoon, H. Developing a community support model for tourism. Ann. Tour. Res. 2011, 38, 964-988. [CrossRef]

21. Nunkoo, R.; Smith, S.L. Political Economy of Tourism: Trust in Government Actors, Political Support, and Their Determinants. Tour. Manag. 2013, 36, 120-132. [CrossRef]

22. Angier, N. When "What Animals Do" Doesn't Seem to Cover It. 2009. Available online: https://faunalytics. org/wp-content/uploads/2015/05/Citation1119.pdf (accessed on 13 June 2020).

23. Bergner, R.M. What is Behaviour? And So What? New Ideas Psychol. 2011, 29, 147-155. [CrossRef]

24. Ward, C.; Berno, T. Beyond Social Exchange Theory. Ann. Tour. Res. 2011, 38, 1556-1569. [CrossRef]

25. Ap, J. Residents' Perceptions on Tourism Impacts. Ann. Tour. Res. 1992, 19, 665-690. [CrossRef]

26. Kayat, K. Power, Social Exchanges and Tourism in Langkawi: Rethinking Resident Perceptions. Int. J. Tour. Res. 2002, 4, 171-191. [CrossRef]

27. Ko, D.-W.; Stewart, W.P. A Structural Equation Model of Residents' Attitudes for Tourism Development. Tour. Manag. 2002, 23, 521-530. [CrossRef] 
28. Vargas-Sánchez, A.; Porras-Bueno, N.; Plaza-Mejía, M.D.L. Ángeles Explaining Residents' Attitudes to Tourism. Ann. Tour. Res. 2011, 38, 460-480. [CrossRef]

29. Perdue, R.R.; Long, P.T.; Allen, L. Resident Support for Tourism Development. Ann. Tour. Res. 1990, 17, 586-599. [CrossRef]

30. Gursoy, D.; Jurowski, C.; Uysal, M. Resident Attitudes: A Structural Modeling Approach. Ann. Tour. Res. 2002, 29, 79-105. [CrossRef]

31. Gursoy, D.; Kendall, K.W. Hosting Mega Events: Modeling Locals' Support. Ann. Tour. Res. 2006, 33, 603-623. [CrossRef]

32. Vargas-Sánchez, A.; Plaza-Mejía, M.D.L.A.; Porras-Bueno, N.; Plaza-Mejia, M.D.L.A. Understanding Residents' Attitudes toward the Development of Industrial Tourism in a Former Mining Community. J. Travel Res. 2008, 47, 373-387. [CrossRef]

33. Dyer, P.; Gursoy, D.; Sharma, B.; Carter, J. Structural Modeling of Resident Perceptions of Tourism and Associated Development on the Sunshine Coast, Australia. Tour. Manag. 2007, 28, 409-422. [CrossRef]

34. Martín, H.S.; Sánchez, M.M.G.D.L.S.; Herrero-Crespo, A. Residents' Attitudes and Behavioural Support for Tourism in Host Communities. J. Travel Tour. Mark. 2017, 35, 231-243. [CrossRef]

35. Vargas-Sánchez, A.; Plaza-Mejía, M.D.L. Ángeles; Porras-Bueno, N. Residents' Attitude to Tourism and Seasonality. J. Travel Res. 2013, 53, 581-596. [CrossRef]

36. Ribeiro, M.A.; Pinto, P.; Silva, J.A.; Woosnam, K.M. Residents' Attitudes and the Adoption of Pro-Tourism Behaviours: The Case of Developing Island Countries. Tour. Manag. 2017, 61, 523-537. [CrossRef]

37. Wu, J.M.-L.; Tsai, H.; Lee, J.-S. Unraveling Public Support for Casino Gaming: The Case of a Casino Referendum in Penghu. J. Travel Tour. Mark. 2016, 34, 398-415. [CrossRef]

38. Krosnick, J.; Richard, D. Attitude Strength: An Overview. In Attitude Strength: Antecedents and Consequences, 1st ed.; Petty, R.E., Krosnick, J.A., Eds.; Lawrance Erlbaum: Hillsdale, NJ, USA, 1995; pp. 1-24.

39. Azjen, I.; Fishbein, M. Understanding Attitudes and Predicting Social Behaviours, 1st ed.; Prentice Hall: Englewood Cliffs, NJ, USA, 1980.

40. Howe, L.C.; Krosnick, J.A. Attitude Strength. Annu. Rev. Psychol. 2017, 68, 327-351. [CrossRef]

41. Livneh, H.; Martz, E. An Introduction to Coping Theory and Research. In Coping with Chronic Illness and Disability; Springer: Boston, MA, USA, 2007; pp. 3-27.

42. Kwon, J.; Vogt, C.A. Identifying the Role of Cognitive, Affective, and Behavioral Components in Understanding Residents' Attitudes toward Place Marketing. J. Travel Res. 2009, 49, 423-435. [CrossRef]

43. Lepp, A. Residents' Attitudes towards Tourism in Bigodi Village, Uganda. Tour. Manag. 2007, 28 , 876-885. [CrossRef]

44. Peters, M.; Chung-Shing, C.; Legerer, A. Local Perception of Impact-Attitudes-Actions Towards Tourism Development in the Urlaubs Region Murtal in Austria. Sustainability 2018, 10, 2360. [CrossRef]

45. Chen, N.C.; Šegota, T. Resident Attitudes, Place Attachment and Destination Branding: A Research Framework. Tour. Hosp. Manag. 2015, 21, 145-158. [CrossRef]

46. Chen, N.C.; Dwyer, L.; Firth, T. Residents' Place Attachment and Word-of-Mouth Behaviours: A Tale of Two Cities. J. Hosp. Tour. Manag. 2018, 36, 1-11. [CrossRef]

47. Jeuring, J.H.G.; Haartsen, T. Destination Branding by Residents: The Role of Perceived Responsibility in Positive and Negative Word-of-Mouth. Tour. Plan. Dev. 2016, 14, 240-259. [CrossRef]

48. Walls, A.; Shani, A.; Rompf, P.D. The Nature of Gratuitous Referrals in Tourism: Local Residents' Perspective. Int. J. Contemp. Hosp. Manag. 2008, 20, 647-663. [CrossRef]

49. Arsal, I.; Woosnam, K.M.; Baldwin, E.D.; Backman, S.J. Residents as Travel Destination Information Providers: An Online Community Perspective. J. Travel Res. 2009, 49, 400-413. [CrossRef]

50. Su, M.M.; Wall, G. Community Participation in Tourism at a World Heritage Site: Mutianyu Great Wall, Beijing, China. Int. J. Tour. Res. 2012, 16, 146-156. [CrossRef]

51. Bagozzi, R.P.; Kimmel, S.K. A Comparison of Leading Theories for the Prediction of Goal-Directed Behaviours. Br. J. Soc. Psychol. 1995, 34, 437-461. [CrossRef]

52. Armstrong, J. Organizational Behavior and Human Decision Processes. Int. J. Forecast. 1988, 4, 513. [CrossRef]

53. Eagly, A.H.; Chaiken, S. The Psychology of Attitudes; Harcourt Brace Jovanovich College Publishers: Orlando, FL, USA, 1993. 
54. Petty, R.E.; Cacioppo, J.T. The Elaboration Likelihood Model of Persuasion. In Communication and Persuasion; Springer Series in Social Psychology; Springer: New York, NY, USA, 1986; pp. 1-24.

55. Kim, M.; Cichy, R. Private Club Members' Perceptions of Social Media. J. Hosp. Tour. Technol. 2017, 8, 119-132. [CrossRef]

56. Kim, Y.H.; Kim, M.; Goh, B.K. An Examination of Food Tourist's Behavior: Using the Modified Theory of Reasoned Action. Tour. Manag. 2011, 32, 1159-1165. [CrossRef]

57. Han, H.; Hsu, L.-T.; Sheu, C. Application of the Theory of Planned Behavior to Green Hotel Choice: Testing the Effect of Environmental Friendly Activities. Tour. Manag. 2010, 31, 325-334. [CrossRef]

58. Amaro, S.; Duarte, P. An Integrative Model of Consumers' Intentions to Purchase Travel Online. Tour. Manag. 2015, 46, 64-79. [CrossRef]

59. Sheeran, P.; Webb, T.L. The Intention-Behavior Gap. Soc. Personal. Psychol. Compass. 2016, 10, $503-518$. [CrossRef]

60. Ossorio, P.G. The Behaviour of Persons; Descriptive Psychology Press: Ann Arbor, MI, USA, 2006.

61. Xiao, H.; Smith, S.L. Source Knowledge for Tourism Research. Ann. Tour. Res. 2005, 32, 272-275. [CrossRef]

62. Journal Citation Reports. Available online: https://jcr.clarivate.com/JCRJournalHomeAction.action?pg= JRNLHOME\&categoryName=HOSPITALITY\%2C\%20LEISURE\%2C\%20SPORT\%20\%26\%20TOURISM\& categories $=$ MW (accessed on 14 August 2020).

63. Simpson, K.; Bretherton, P. The Impact of Community Attachment on Host Society Attitudes and Behaviours Towards Visitors. Tour. Hosp. Plan. Dev. 2009, 6, 235-246. [CrossRef]

64. Ayazlar, R.A.; Ayazlar, G. Residents' Tourism Support Behaviour: The Role of Sustainable Tourism Attitude. Enlightening Tourism. A Pathmaking J. 2016, 6, 124-149.

65. Rasoolimanesh, S.M.; Ringle, C.M.; Jaafar, M.; Ramayah, T. Urban vs. rural destinations: Residents' perceptions, community participation and support for tourism development. Tour. Manag. 2017, 60, 147-158. [CrossRef]

66. López, M.F.B.; Virto, N.R.; Manzano, J.A.; Miranda, J.G.-M. Residents' Attitude as Determinant of Tourism Sustainability: The Case of Trujillo. J. Hosp. Tour. Manag. 2018, 35, 36-45. [CrossRef]

67. Su, L.; Huang, S.; Huang, J. Effects of Destination Social Responsibility and Tourism Impacts on Residents' Support for Tourism and Perceived Quality of Life. J. Hosp. Tour. Res. 2016, 42, 1039-1057. [CrossRef]

68. Schnitzer, M.; Walde, J.; Scheiber, S.; Nagiller, R.; Tappeiner, G. Does the Young Residents' Experience with the Youth Olympic Games Influence the Support for Staging the Olympic Games? Tour. Manag. Perspect. 2019, 30, 220-231. [CrossRef]

69. Chen, Z.; Wang, Y.; Li, X.; Lawton, L.J. It's Not Just Black or White: Effects of Ambivalence on Residents' Support for a Mega-Event. J. Hosp. Tour. Res. 2018, 43, 283-313. [CrossRef]

70. Monterrubio, C.; Andriotis, K.; Rodríguez-Muñoz, G. Residents' Perceptions of Airport Construction Impacts: A Negativity Bias Approach. Tour. Manag. 2020, 77, 103983. [CrossRef]

71. Spencer, D.M.; Nsiah, C. The Economic Consequences of Community Support for Tourism: A Case Study of a Heritage Fish Hatchery. Tour. Manag. 2013, 34, 221-230. [CrossRef]

72. Maruyama, N.; Woosnam, K.M. Residents' Ethnic Attitudes and Support for Ethnic Neighborhood Tourism: The Case of a Brazilian Town in Japan. Tour. Manag. 2015, 50, 225-237. [CrossRef]

73. Strzelecka, M.; Boley, B.B.; Woosnam, K.M. Place Attachment and Empowerment: Do Residents Need to be Attached to be Empowered? Ann. Tour. Res. 2017, 66, 61-73. [CrossRef]

74. Lee, T.H. Influence Analysis of Community Resident Support for Sustainable Tourism Development. Tour. Manag. 2013, 34, 37-46. [CrossRef]

75. Zhou, Q.; Zhang, J.; Zhang, H.; Ma, J. A Structural Model of Host Authenticity. Ann. Tour. Res. 2015, 55, 28-45. [CrossRef]

76. Ritchie, B.W.; Chien, P.M.; Shipway, R. A Leg(acy) to Stand on? A Non-Host Resident Perspective of the London 2012 Olympic Legacies. Tour. Manag. 2020, 77, 104031. [CrossRef]

77. McGehee, N.G.; Andereck, K.L. Factors Predicting Rural Residents' Support of Tourism. J. Travel Res. 2004, 43, 131-140. [CrossRef]

78. Lee, C.; Back, K. Examining Structural Relationships Among Perceived Impact, Benefit, and Support for Casino Development Based on 4th Year Longitudinal Data. Tour. Manag. 2006, 27, 466-480. [CrossRef] 
79. Kang, S.K.; Lee, C.-K.; Yoon, Y.; Long, P.T. Resident Perception of the Impact of Limited-Stakes Community-Based Casino Gaming in Mature Gaming Communities. Tour. Manag. 2008, 29, 681-694. [CrossRef]

80. Wang, Y.; Pfister, R.E. Residents' Attitudes Toward Tourism and Perceived Personal Benefits in a Rural Community. J. Travel Res. 2008, 47, 84-93. [CrossRef]

81. Draper, J.; Woosnam, K.M.; Norman, W.C. Tourism Use History: Exploring a New Framework for Understanding Residents' Attitudes toward Tourism. J. Travel Res. 2009, 50, 64-77. [CrossRef]

82. Nicholas, L.N.; Thapa, B.; Ko, Y.J. Residents' Perspectives of a World Heritage Site. Ann. Tour. Res. 2009, 36, 390-412. [CrossRef]

83. Lee, C.-K.; Kang, S.K.; Long, P.; Reisinger, Y. Residents' Perceptions of Casino Impacts: A Comparative Study. Tour. Manag. 2010, 31, 189-201. [CrossRef]

84. Chien, P.M.; Ritchie, B.W.; Shipway, R.; Henderson, H. I Am Having a Dilemma. J. Travel Res. 2011, 51, 451-463. [CrossRef]

85. Latkova, P.; Vogt, C.A. Residents' Attitudes toward Existing and Future Tourism Development in Rural Communities. J. Travel Res. 2011, 51, 50-67. [CrossRef]

86. Nunkoo, R.; Ramkissoon, H. Power, Trust, Social Exchange and Community Support. Ann. Tour. Res. 2012, 39, 997-1023. [CrossRef]

87. Woosnam, K.M. Using Emotional Solidarity to Explain Residents' Attitudes about Tourism and Tourism Development. J. Travel Res. 2011, 51, 315-327. [CrossRef]

88. Kaplanidou, K.; Karadakis, K.; Gibson, H.; Thapa, B.; Walker, M.; Geldenhuys, S.; Coetzee, W. Quality of Life, Event Impacts, and Mega-Event Support among South African Residents Before and After the 2010 FIFA World Cup. J. Travel Res. 2013, 52, 631-645. [CrossRef]

89. Boley, B.B.; McGehee, N.G.; Perdue, R.R.; Long, P. Empowerment and Resident Attitudes toward Tourism: Strengthening the Theoretical Foundation through a Weberian Lens. Ann. Tour. Res. 2014, 49, 33-50. [CrossRef]

90. Stylidisa, D.; Biran, A.; Sit, J.; Szivas, E. Residents' Support for Tourism Development: The Role of Residents' Place Image and Perceived Tourism Impacts. Tour. Manag. 2014, 45, 260-274. [CrossRef]

91. Stylidisa, D.; Terzidou, M. Tourism and the Economic Crisis in Kavala, Greece. Ann. Tour. Res. 2014, 44, 210-226. [CrossRef]

92. Jaafar, M.; Noor, S.M.; Rasoolimanesh, S.M. Perception of Young Local Residents Toward Sustainable Conservation Programmes: A Case Study of the Lenggong World Cultural Heritage Site. Tour. Manag. 2015, 48, 154-163. [CrossRef]

93. Sinclair-Maragh, G.; Gursoy, D. Imperialism and Tourism: The Case of Developing Island Countries. Ann. Tour. Res. 2015, 50, 143-158. [CrossRef]

94. Wang, S.; Chen, J.S. The Influence of Place Identity on Perceived Tourism Impacts. Ann. Tour. Res. 2015, 52, 16-28. [CrossRef]

95. Wang, S.; Xu, H. Influence of Place-Based Senses of Distinctiveness, Continuity, Self-Esteem and Self-Efficacy on Residents' Attitudes Toward Tourism. Tour. Manag. 2015, 47, 241-250. [CrossRef]

96. Woo, E.; Kim, H.; Uysal, M. Life satisfaction and Support for Tourism Development. Ann. Tour. Res. 2015, 50, 84-97. [CrossRef]

97. Liang, Z.-X.; Hui, T.-K. Residents' Quality of Life and Attitudes toward Tourism Development in China. Tour. Manag. 2016, 57, 56-67. [CrossRef]

98. Nunkoo, R.; So, K.K.F. Residents' Support for Tourism: Testing Alternative Structural Models. J. Travel Res. 2016, 55, 847-861. [CrossRef]

99. Al-Emadi, A.; Kaplanidou, K.; Diop, A.; Sagas, M.; Le, K.T.; Mustafa, S.A. 2022 Qatar World Cup: Impact Perceptions among Qatar Residents. J. Travel Res. 2016, 56, 678-694. [CrossRef]

100. Chi, C.G.-Q.; Cai, R.; Li, Y. Factors Influencing Residents' Subjective Well-Being at World Heritage Sites. Tour. Manag. 2017, 63, 209-222. [CrossRef]

101. Gursoy, D.; Yolal, M.; Ribeiro, M.A.; Netto, A.P. Impact of Trust on Local Residents' Mega-Event Perceptions and Their Support. J. Travel Res. 2016, 56, 393-406. [CrossRef]

102. Moghavvemi, S.; Woosnam, K.M.; Paramanathan, T.; Musa, G.; Hamzah, A. The Effect of Residents' Personality, Emotional Solidarity, and Community Commitment on Support for Tourism Development. Tour. Manag. 2017, 63, 242-254. [CrossRef] 
103. Olya, H.; Gavilyan, Y. Configurational Models to Predict Residents' Support for Tourism Development. J. Travel Res. 2016, 56, 893-912. [CrossRef]

104. Ouyang, Z.; Gursoy, D.; Sharma, B. Role of Trust, Emotions and Event Attachment on Residents' Attitudes toward Tourism. Tour. Manag. 2017, 63, 426-438. [CrossRef]

105. Rasoolimanesh, S.M.; Jaafar, M.; Barghi, R. Effects of Motivation, Knowledge and Perceived Power on Residents' Perceptions: Application of Weber's Theory in World Heritage Site Destinations. Int. J. Tour. Res. 2016, 19, 68-79. [CrossRef]

106. Zuo, B.; Gursoy, D.; Wall, G. Residents' Support for Red Tourism in China: The Moderating Effect of Central Government. Ann. Tour. Res. 2017, 64, 51-63. [CrossRef]

107. Chi, C.G.-Q.; Ouyang, Z.; Xu, X. Changing Perceptions and Reasoning Process: Comparison of Residents' Pre and Post-Event Attitudes. Ann. Tour. Res. 2018, 70, 39-53. [CrossRef]

108. Lee, C.; Kim, J.; Kim, J.S. Impact of a Gaming Company's CSR on Residents' Perceived Benefits, Quality of Life, and Support. Tour. Manag. 2018, 64, 281-290. [CrossRef]

109. Woosnam, K.M.; Draper, J.; Jiang, J.; Aleshinloye, K.D.; Erul, E. Applying Self-Perception Theory to Explain Residents' Attitudes about Tourism Development through Travel Histories. Tour. Manag. 2018, 64, 357-368. [CrossRef]

110. Garau-Vadell, J.B.; Gutiérrez-Taño, D.; Díaz-Armas, R.J. Residents' Support for P2P Accommodation in Mass Tourism Destinations. J. Travel Res. 2018, 58, 549-565. [CrossRef]

111. Kock, F.; Josiassen, A.; Assaf, A.G.; Karpen, I.; Farrelly, F. Tourism Ethnocentrism and Its Effects on Tourist and Resident Behaviour. J. Travel Res. 2019, 58, 427-439. [CrossRef]

112. Ouyang, Z.; Gursoy, D.; Chen, K.C. It's All about Life: Exploring the Role of Residents' Quality of Life Perceptions on Attitudes toward a Recurring Hallmark Event Over Time. Tour. Manag. 2019, 75, 99-111. [CrossRef]

113. Papastathopoulos, A.; Ahmad, S.Z.; Al Sabri, N.; Kaminakis, K. Demographic Analysis of Residents' Support for Tourism Development in the UAE: A Bayesian Structural Equation Modeling Multigroup Approach. J. Travel Res. 2019, 59, 1119-1139. [CrossRef]

114. Gannon, M.; Rasoolimanesh, S.M.; Taheri, B. Assessing the Mediating Role of Residents' Perceptions toward Tourism Development. J. Travel Res. 2020. [CrossRef]

115. Kanwal, S.; Rasheed, M.I.; Pitafi, A.H.; Pitafi, A.H.; Ren, M. Road and Transport Infrastructure Development and Community Support for Tourism: The Role of Perceived Benefits, and Community Satisfaction. Tour. Manag. 2020, 77, 104014. [CrossRef]

116. Yeager, E.P.; Boley, B.B.; Woosnam, K.M.; Green, G.T. Modeling Residents' Attitudes toward Short-term Vacation Rentals. J. Travel Res. 2019, 59, 955-974. [CrossRef] 